Agriculture

Publication 1851/E

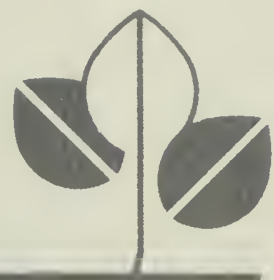

\title{
Protection of farm-stored
} grains and oilseeds from insects, mites, and molds I*I Aanculure MAR 131991

Library / Bibliothèque, Ottawa K1A 0C5
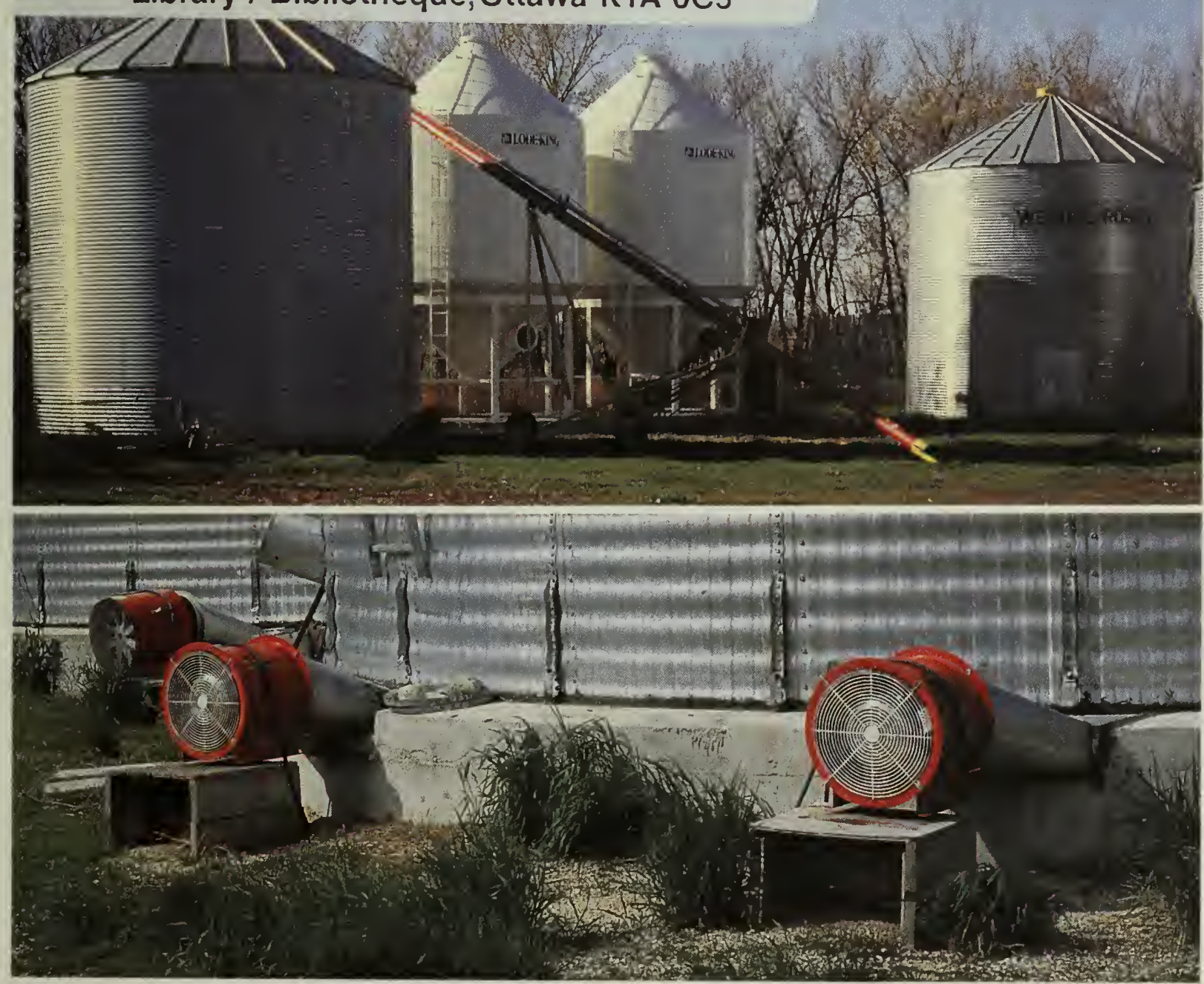
Digitized by the Internet Archive in 2012 with funding from

Agriculture and Agri-Food Canada - Agriculture et Agroalimentaire Canada 


\title{
Protection of farm-stored grains and oilseeds from insects, mites, and molds
}

\author{
Edited by \\ J.T. Mills \\ Research Station \\ Winnipeg, Man.
}

Recommendations for pesticide use in this publication are intended as guidelines only. Any application of a pesticide must be in accordance with directions printed on the product label of that pesticide as prescribed under the Pest Control Products Act. Always read the label. A pesticide should also be recommended by provincial authorities. Because recommendations for use may vary from province to province, your provincial agricultural representatives should be consulted for specific advice.

\section{Cover illustration}

(Top) Typical steel bins used for farm grain storage in western Canada; (bottom) axial fans used for aerating grain at Argyle, Man.

Agriculture Canada Publication 1851/E available from

Communications Branch, Agriculture Canada

Ottawa K1A 0C7

- Minister of Supply and Services Canada 1990

Cat. No. A43-1851/1990E ISBN 0-662-17822-X

Printed 1990 23M-12:90

Produced by Research Program Service

This publication replaces publication $1595 / \mathrm{E}$,

Insects, mites, and molds in farm-stored grain in the Prairie Provinces

Également disponible en français sous le titre

Protection des grains et des graines oléagineuses stockés à la ferme contre les insectes, les acariens et les moisissures 


\section{PREFACE}

This booklet describes pests of farm-stored grains and oilseeds and outlines methods for their prevention, detection, and control. Prolonged storage of such crops occurs mainly on the farm, so pests are most likely to cause damage in farm bins. To avoid or control damage caused by pests, the producer needs to understand the problem and use current control practices. The safe storage methods that we promote here are based on sound management practices and a general knowledge of insects, mites, and molds. We emphasize the use of cool temperatures through aeration to protect stored crops.

This publication replaces Insects, mites, and molds in farm-stored grain in the Prairie Provinces, 1982, Agriculture Canada Publication 1595/E. It contains updated information, applicable across Canada, on pests of farm-stored grains and oilseeds. The title has been changed to emphasize the availability and use of practical protection procedures.

\section{Contributors}

D. Abramson Research Station, Agriculture Canada, Winnipeg, Man.

P.S. Barker Research Station, Agriculture Canada, Winnipeg, Man.

O. Friesen Manitoba Agriculture, Winnipeg, Man.

L. Harris Saskatchewan Agriculture, Regina, Sask.

J.T. Mills Research Station, Agriculture Canada, Winnipeg, Man.

W.E. Muir Department of Agricultural Engineering, University of Manitoba, Winnipeg, Man.

D.T. Sager United Grain Growers, Winnipeg, Man.

R.N. Sinha Research Station, Agriculture Canada, Winnipeg, Man.

J. van Loon Canadian Grain Commission, Winnipeg, Man.

N.D.G. White Research Station, Agriculture Canada, Winnipeg, Man. 


\section{CONTENTS}

Preface 4

Good storage practices 6

Introduction 7

Protecting stored products 8

Types of storage 8

Prevention of spoilage 8

Aeration 10

In-bin drying with outside air 11

In-bin drying with heated air 12

Prevention of infestations 12

Insects 12

Mites 13

Storage fungi 13

Detecting problems 14

Spoilage and infestations 16

Bin monitoring 18

Identifying the organisms 21

Common stored-product pests 21

Beetles 22

Psocids 27

Moths 28

Mites 28

Storage fungi 32

Mycotoxins 32

Controlling infestations 33

Cooling and cleaning the product 33

Treating with insecticides 34

Cautions for spray operators 36

Use of concentrates 36

Grain treatment 36

Fumigating 37

Application 38

Cautions for fumigators 39

Further information 40

Acknowledgments 40

Common and scientific names of major pests in stored grain 41

References 42

Additional reading 43

Appendix 45 


\section{GOOD STORAGE PRACTICES}

- Prevent losses from insects, mites, and molds by storing grain and oilseed crops properly; preventing infestations is easier, safer, and less expensive than controlling them.

- Prepare the bin, before storing the new crop: sweep or vacuum the floor and walls; burn or bury sweepings that contain spoiled or infested grain; seal cracks to keep out flying insects from outside, rain, and snow; and spray the walls and floors with a recommended insecticide.

- Install an aeration system to reduce temperature gradients and moisture condensation.

- Dry tough or damp crops soon after harvest as they are more likely to heat and become infested with insects and mites than dry (straight-grade) crops; then cool after drying.

- Examine stored crops every 2 weeks for signs of heating or infestation; either check temperatures, carbon dioxide levels, and insect activity by traps, or probe and screen samples.

- Move heated or infested crops into another bin if outdoor temperatures are sufficiently cold to break up hot-spots and control infestation.

- Check the top of binned crops and remove snow, if present, before a crust of mold develops.

- Observe safety precautions when applying insecticides; only persons experienced with fumigation procedures should apply fumigants. Some provincial regulations require that persons applying fumigants be registered. 


\section{INTRODUCTION}

Protecting stored grain and oilseed crops from spoilage is an essential part of their production; failure to do so may result in their being downgraded. Heated or insect- and mite-infested crops in storage quickly lose weight and quality and may cost individual farmers thousands of dollars in lost income. Storing grains and oilseeds cool and dry in clean, uninfested bins that are weatherproof and well aerated prevents such losses, maintains quality, and assures saleability.

The small, light-avoiding insect and mite pests of stored crops can penetrate deep into bulk-stored crops. In empty bins, they hide in cracks and crevices where they survive in residues until a newly harvested crop arrives. Most do not attack field crops and are not harvested with the grain, although rice weevils and lesser grain borers infest cereals in the field in warm climates. Stored-product pests also feed on dried animal and vegetable matter and on molds; some survive on food that contains as little as $8 \%$ moisture. Coldhardy insects can survive the winter in stored crops. During summer, some fly and can be carried by the wind from infested grain residues and animal feeds in heated buildings to granaries and even into houses.

In Canada many of the insect and mite pests of stored grain and oilseed crops are cold hardy; these pests manage to survive the winter by finding protected habitats among the seeds or by adaptation to cold, or by changing to a nonfeeding, hardy life stage, as in some mites. Insects rarely reproduce at temperatures below about $17^{\circ} \mathrm{C}$ and mites below $3^{\circ} \mathrm{C}$, but, when stored crops heat up, insects, especially the rusty grain beetle and red flour beetle, multiply rapidly and do much damage. The moisture content of grain also affects the extent to which insects and mites infest stored crops and cause them to heat and spoil. The insects, mites, and molds that cause grains and oilseeds to heat and lose condition are inactive at low temperatures (below about $8^{\circ} \mathrm{C}$ for insects, $0^{\circ} \mathrm{C}$ for mites, and $-8^{\circ} \mathrm{C}$ for molds). Crops stored in small bins cool more rapidly and evenly during winter than in larger bins that are not aerated. Dry (straight-grade) grain or oilseed crops are less prone to spoilage than tough or damp crops. Tough grains and oilseeds are particularly prone to mite infestation. Canola is often infested by mites and molds even when the crop has a straight-grade rating.

Harvested grain or oilseed crops normally contain small amounts of storage molds (or storage fungi) that develop during storage and cause spoilage. Molds develop rapidly in crops that are stored either tough or damp during warm weather. Under certain harvest and storage conditions, some fungi may produce poisonous substances called mycotoxins.

Stored grain or oilseed problems are best understood when bulk grain is considered as an ecosystem in which living organisms (e.g., 
grains, insects, mites, and molds) and their nonliving environment (e.g., temperature, moisture, and oxygen) interact with one another. Grain quality usually declines slowly, but, when certain conditions occur in undisturbed bulks, spoilage is faster; complete loss of the crop quality may follow.

\section{PROTECTING STORED PRODUCTS}

\section{TYPES OF STORAGE}

Well-constructed, weather-proofed bins are essential to prevent infestations and to preserve crop quality during long-term storage. Bins on high, well-drained land protect the crop from heavy rainfall and spring floods. Steel bins, when empty, provide fewer places for insects to breed than empty wooden granaries.

Erect steel bins on steel-reinforced concrete slabs to prevent cracks and moisture transfer through the floor. Use a caulking compound to fill both cracks in the floor and open joints between the floor and wall. Shape the concrete pads slightly convex to shed water. Fill no higher than the top ring, leaving ample head room above the surface of the grain for inspection and sampling. Install aeration systems that cool the stored crop and reduce moisture migration to minimize the risk of spoilage and insect or mite infestations during storage.

When yields are above average, crops are often stored in machinery sheds or barns. Take extra care to prevent spoilage when using these types of storage. Fill cracks in concrete floors with a caulking compound. The double walls in barns often contain infested grain dust. Remove the bottom boards to clean out the debris and apply insecticide sprays or dusts in the spaces between the studs.

For temporary crop storage, plywood sheets can be used to construct circular cribs. Locate cribs on high, dry land and cone the ground under the grain so that rain and melted snow water can drain away. Clear away grass or straw so that mice are not given shelter around the crib. Cone the grain as high as possible at the centre to shed rain and snow and to avoid a space between the top edge of the crib and the grain surface. If a plastic sheet is placed over the coned grain, tie down the sheet with fish netting or place several old tires on top of the sheet to prevent it from flapping and tearing in the wind. Corner-vented sheets are designed to permit the escape of moisture but may allow in more snow than unvented sheets.

\section{PREVENTION OF SPOILAGE}

The quality of grains and oilseeds can be maintained economically by forcing air through bulk-stored crops. Air is blown in or sucked out by means of a fan (Fig. 1) attached to a bin equipped with either a 


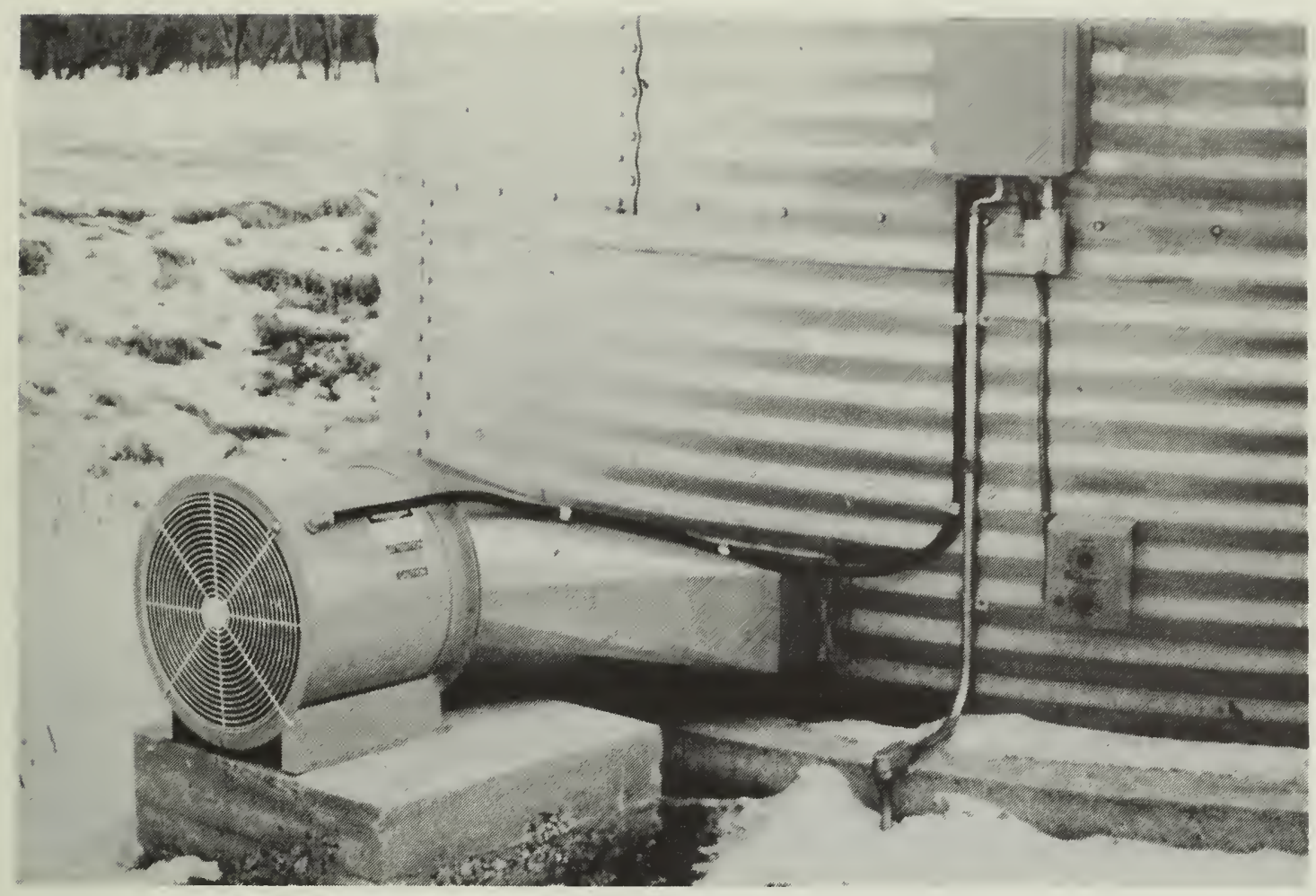

Fig. 1 Aeration unit.

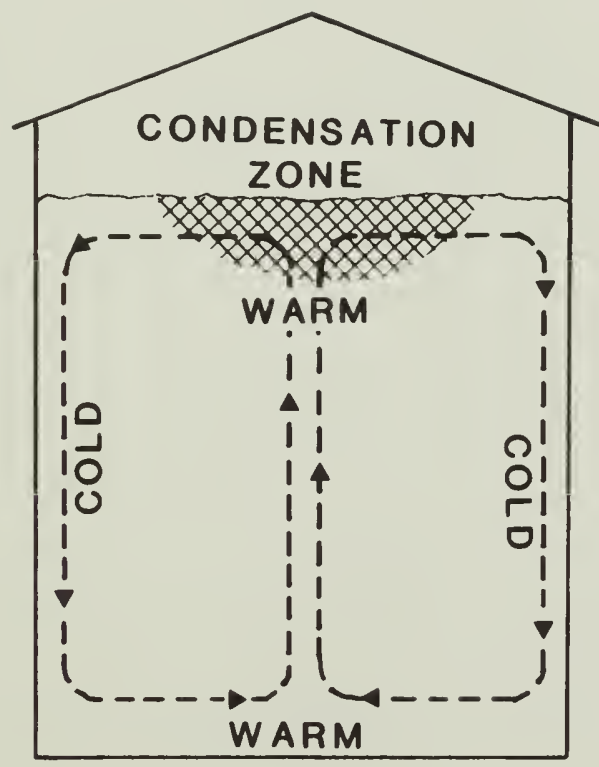

Fig. 2 Moisture migration in an unventilated bin during autumn and winter. 
perforated duct or a perforated floor. When air is blown in, the last part of the bulk to cool will be the top layer. Check from the top to determine whether the whole bulk is cooled or whether spoilage has begun. In both fall and winter, most spoilage begins near the top centre of the bulk where moisture condensation is greatest (Fig. 2). If the air is sucked out by reversing the airflow, the last part to cool is the bottom layer. In this case spoilage may occur at the bottom of the bin where it is much more difficult to control or monitor.

Producers have three options for moving air through bins as a means of preventing spoilage:

- aeration

- in-bin drying with near-ambient air

- in-bin drying with heated air.

\section{Aeration}

Purpose The purpose of an aeration system is to preserve stored grain or stored product by cooling and preventing moisture migration. (Do not expect a properly designed and operated aeration system to dry the grain or oilseed, although some drying may take place.) Aeration helps to conserve the quality of malting barley without pesticide residues, fungal cdors, or germination damage.

Airflow rate In aeration systems the usual airflow rates per cubic metre of grain or oilseed are about 1-2 L/s.

Fan size Usually relatively small fans are required for aeration purposes. A cylindrical bin, $6.4 \mathrm{~m}$ in diameter and with a $6.8-\mathrm{m}$ eave height, filled with $215 \mathrm{~m}^{3}$ ( $6000 \mathrm{bu}$ ) of wheat may require a fan of only $250-600 \mathrm{~W}$ (exact size depends on the actual performance of the specific make and size of fan). Select a fan by following the Manitoba Agriculture booklets: Grain aeration and unheated air drying and Fan test results (Friesen and Huminicki 1987a and $b$ ).

When the main purposes of the ventilation system are to cool the crop and prevent moisture migration, the nonuniform airflow patterns developed by ducts placed on or in the floor are usually acceptable. A completely perforated floor usually produces a uniform air flow throughout the bulk and reduces the chance of unventilated spoilage pockets developing. Install trap doors in perforated floors and ducts to facilitate removal of crop residue build-up that can harbor pests.

Under hot, humid harvesting conditions, such as often occur in southwest Ontario during late July and August, aeration by warm, humid air can result in condensation. Condensed moisture from the inner bin roof drips onto the bulk surface creating mold crusts and stimulating insect populations. In this case cross-ventilation to remove warm air rising from the bulk surface is effective before condensation occurs. Begin aeration only when air temperatures have moderated. 
Fan operation Forced movement of cool, outside air through grains or oilseeds causes a cooling front to move through the bulk from the air entrance to the air exit. Aeration per cubic metre of grain or oilseed at an airflow rate of $1 \mathrm{~L} / \mathrm{s}$ requires about $240 \mathrm{~h}$ or about 10 days of continuous operation to pass a cooling front completely through the bulk. Do not turn off the fan until the seeds on top have the same temperature as the outside air. During initial cooling after harvest the moisture content of the cooled crop may be reduced by about 0.5$1.0 \%$.

Normally the best management strategy is to run the fan continuously after harvest until the temperature of the stored crop has been cooled down below $20^{\circ} \mathrm{C}$. When the outside air temperature has further dropped to about $5^{\circ} \mathrm{C}$ below the crop temperature, operate the fan again continuously until the new cooling front has passed through the bulk. In winter, crop storage temperatures should normally be between $-5^{\circ} \mathrm{C}$ and $+5^{\circ} \mathrm{C}$.

\section{In-bin drying with outside air}

Drying process Moisture can be removed from stored crops by passing outside air through the bulk. In western Canada, except for the winter months, outside air can be used with heat added only by the fan and motor. Grain in a ventilated bin begins to dry where the air enters the bulk, usually at the bottom of the bin. A drying front develops and moves slowly upward through the bulk. Below the drying front the grain is at the temperature of the incoming air and at a moisture content in equilibrium with the incoming air. For example, incoming air at $70 \%$ relative humidity will result in a moisture content of about $14-15 \%$ for wheat or $8-9 \%$ for canola. The grain above the drying front will remain at a moisture content within about $1 \%$ of its initial storage condition. The drying front must be moved through the bulk before spoilage occurs. The rate of movement of the drying front is mainly affected by the airflow rate per unit mass of grain or oilseed.

To dry all the stored crop in the least possible time requires a uniform air pattern throughout the bulk. The airflow pattern in a bin equipped with a completely perforated floor and a leveled grain surface is uniform unless a centre core of densely packed grain and dockage develops under the filling spout. In bins with poor transitions from the fans to the plenum under the floor, airflow through the bulk near the fan entrances is reduced.

Airflow selection To obtain the lowest equipment and operating costs, determine the lowest possible airflow. Minimum airflows for inbin drying are chosen so that the crop dries just before it undergoes unacceptable spoilage. Minimum airflow rates for drying wheat, barley, and canola in the worst drying years between 1953 and 1985 are given in the Manitoba Agriculture booklet Grain aeration and unheated air drying (Friesen and Huminicki 1987a). It is 
recommended that farmers contact their local provincial agricultural engineers for airflow and equipment recommendations.

Bin selection Increasing the height-to-diameter ratio of the bin increases the size and energy consumption of the fan required. The reduced cost of drying less depth of grains or oilseeds must be balanced against the increased costs of steel and concrete as bin diameter is increased to store the same quantity of grain.

Fan operation Run the fan continuously in the fall until either the crop temperature has been brought down to $0^{\circ} \mathrm{C}$ or is dry. In the spring, if drying was not completed the previous fall and no spoilage has occurred, then continue drying when the air temperature begins to rise above $0^{\circ} \mathrm{C}$. Even under humid or rainy conditions operate the fan continuously. Even though moist air will rewet the bottom slightly, the main drying front will continue moving through the bulk. As long as the fan is continued in operation for a few days after the humid period, the rewetting will distribute through the bulk and will probably not cause spoilage. Rewetting can be an economic benefit if the grain at the bottom has overdried below the maximum allowed selling moisture content. Although it improves the storage quality, any drying below this regulatory value reduces the saleable mass, and thus the monetary value, of the bulk. Rewetting, however, causes the grains or oilseeds to expand and may cause structural failure of the bin walls.

\section{In-bin drying with heated air}

Increasing the temperature reduces the relative humidity of air entering the bulk. For example, increasing the temperature of $20^{\circ} \mathrm{C}$ air at $70 \%$ relative humidity to $25^{\circ} \mathrm{C}$ reduces the relative humidity to $50 \%$. Wheat exposed to the $70 \%$ air will dry to $14-15 \%$ moisture content whereas at $50 \%$ relative humidity the wheat will dry to $10-$ $11 \%$. Although this grain will store much better than the $14-15 \%$ wheat, its saleable mass will have been reduced by about $4-5 \%$ causing a similar reduction in its economic value under present marketing regulations. Thus, heat added by propane heaters, furnaces, solar collectors, and so on is commonly uneconomic. Usually the extra heat is an economic benefit only when the relative humidity of the outside air remains high for many days, such as in parts of eastern Canada. Under some conditions adding heat requires a larger fan and more-rapid drying because the crop spoils more rapidly.

\section{PREVENTION OF INFESTATIONS}

\section{Insects}

To prevent and control infestations we need to know where and when insects occur. Surveys have shown that most empty granaries 
are infested with low numbers of insects and mites. Animal feeds, trucks, and farm machinery are other sources of insect infestations. Some insects can fly as well as walk, which increases their ability to infest stored crops. Take the following measures before the crop is harvested to prevent infestation and spoilage during storage.

- Keep dockage to a minimum by controlling weeds in the growing crop; insects do not multiply extensively in stored crops that contain low amounts of dockage.

- Clean granaries preferably with a vacuum cleaner; burn or bury the sweepings.

- Repair and weatherproof granaries before filling with grains or oilseeds.

- Do not allow waste grain or feed to accumulate either inside or outside storage structures.

- Eliminate grass and weeds around granaries.

- Do not store crops in bins next to animal feeds that are likely to be infested.

- Spray the walls and floor of empty granaries with an approved insecticide about 1 week before crop storage.

- Examine grains and oilseeds that have been binned tough every 2 weeks: (1) push your hand into the surface at various points to feel for warmth or crusts; and (2) insert a metal rod into the bulk to test for heating at various depths; after at least $15 \mathrm{~min}$, preferably $60 \mathrm{~min}$, withdraw the metal rod and test for warmth on the wrist or palm of the hand.

- Store new grains or oilseeds only in clean, empty bins; bins that contain old grain might be infested.

- Try and sell for feed your high-moisture grains first.

- Remember that cool, dry grains or oilseeds seldom spoil.

\section{Mites}

Mite infestations can be prevented and or controlled by the following procedures:

- Keep the moisture content of cereal grain below $12 \%$ and that of canola below $8 \%$.

- Transfer the grain or oilseed to an empty bin to break up moist pockets, or chill cereal grain of 15-16\% moisture content with forced air movement during winter.

\section{Storage fungi}

To prevent storage mold activity, give particular attention to the moisture and temperature of the bulk at binning, especially in unaerated bins. Monitor bulk temperatures at 1-or 2-week intervals. Dry high-moisture and cool high-temperature grains or oilseeds by aeration (see "Prevention of spoilage"). Use spreaders to disperse throughout the bulk: small, broken, and shriveled kernels; weed 
seeds; chaff; and straw. Remember that the increased bulk density in the bin much reduces the rate of forced airflow through the bulk. Remove windblown snow before it melts and provides a focus for mold development. To control heating or spoilage in progress, move the bulk to cool it and break up high-moisture pockets. Alternatively, aerate or dry the bulk. Have someone with you when climbing into or onto granaries. Wear a protective mask to prevent inhalation of mold spores either when breaking up a moldy crust within a bin or when handling spoiled grains or oilseeds.

\section{DETECTING PROBLEMS}

Inspect grain and oilseed stocks regularly to detect the first signs of infestation or spoilage. Sample bulks every 2 weeks to check for insects and heating. To detect insects, warm the sampled grain or oilseed in a screened funnel for several hours (Fig. 3). Insects and mites move away from the gradually drying grain and fall into a collecting bottle.

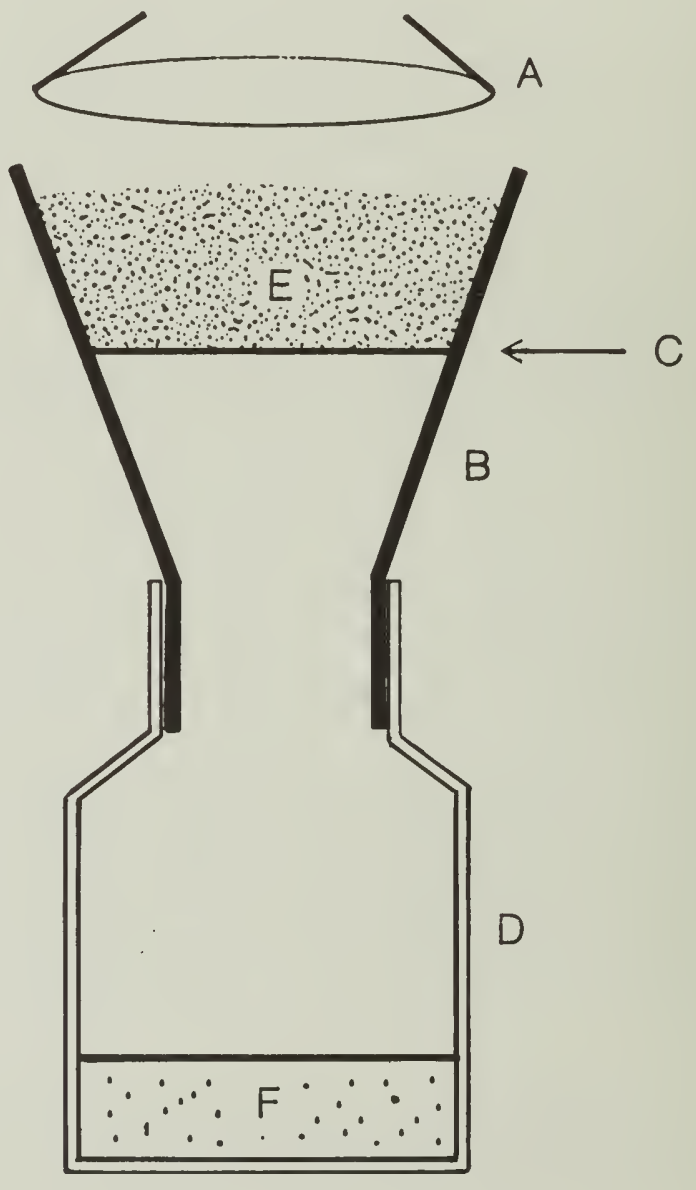

Fig. 3 Apparatus for extracting insects and mites from grains and oilseeds: $A$, light bulb; $B$, metal funnel; $C$, metal screen soldered to funnel wall; $D$, glass jar; $E, 200 \mathrm{~g}$ of grain; and $F, 50 \mathrm{ml}$ of $70 \%$ alcohol or water. 
Another way to check for insects in cereals is to screen surface samples using a No. 10 sieve (2.0-mm aperture). For the smaller canola seeds use a No. 20 sieve $(0.85-\mathrm{mm}$ aperture). Use a sampling probe to obtain deep samples. Warm the siftings for a few minutes and then examine them for insect movement. Check grains and oilseeds for heating by feeling the bulk's surface and a metal pipe after it has been inserted for $1 \mathrm{~h}$ within the bulk.

To check for mites, sift grain or oilseed samples through a No. 20 or 30 mesh sieve (0.595-mm aperture). Warm the dust and screenings to room temperature and examine them through a magnifying glass. Large numbers of mites in siftings look like clumps of moving dust. Smaller numbers that look like specks of dust are hard to see.

Insect-detection devices used to trap insects consist of probes, or plastic tubes perforated with small holes that exclude grain kernels but allow insects to drop into, but not to escape from, the trap (Fig. 4). Traps are generally not used in oilseeds where insects are usually not a problem.

As a monitoring device, traps can detect infestations early so that producers or elevator managers can act before the grain has deteriorated to the point at which serious losses occur. Traps can be

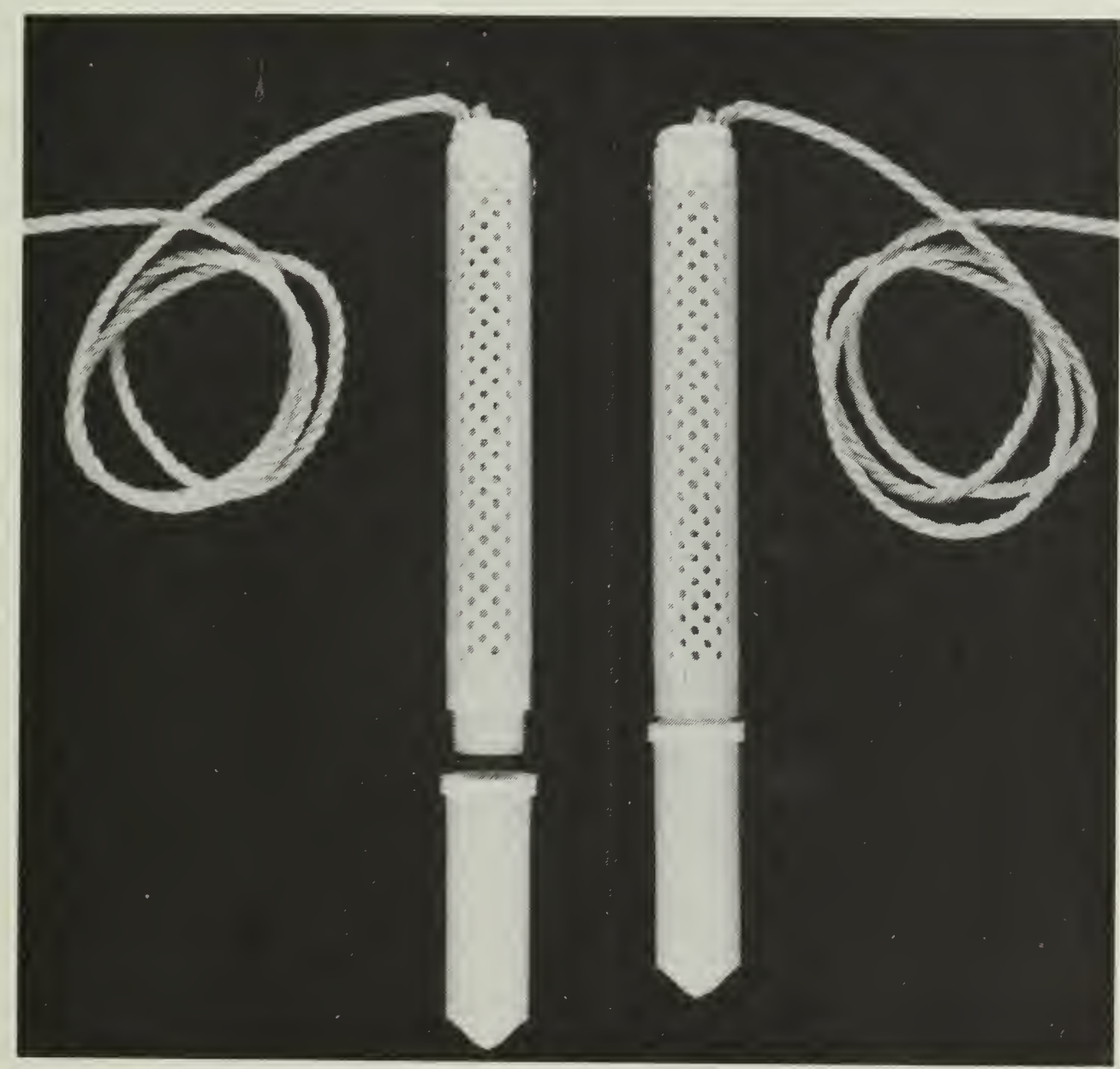

Fig. 4 Plastic trap for detecting stored-product insects. 
used in granaries, elevators, rail cars, and ships to monitor grain at all stages of storage and transport. Push traps into the centre of a grain mass where insects generally accumulate because of warmth and higher moisture. Leave them for about 1 week (adult insects of some cold-hardy species continue to be captured down to $8^{\circ} \mathrm{C}$ ) and remove by pulling on an attached rope. Take care to identify captured insects because grain-feeding pests require chemical control measures, whereas fungus-feeding insects indicate the grain is going out of condition and should be moved into another bin.

\section{SPOILAGE AND INFESTATIONS}

Development of storage fungi and insects is favored by moisture and moderate-to-high temperatures. Continuing growth of these organisms in grains and oilseeds results in spoilage, heating, and insect infestations.

Even when grains and oilseeds have been stored dry, moist spots may develop by moisture migration within the bulk or by rain or snow getting in through roof vents and other openings.

Grain along the inner perimeter and roof of the bin cools as the outside-air temperature decreases during fall and winter. Grain in the centre of large, unaerated bins (6-m diameter and larger) remains near the harvest temperature into mid-to-late winter. This temperature difference within the bulk causes air to move up through the warm bulk at the centre. As warm, moist air moves upward, cooler grain at the top of the bulk absorbs moisture from the air. Moisture in this rising air may also condense or freeze on the underside of cold roofs (Fig. 2).

Tough and damp crops (Table 1) delivered to the elevator must be dried before they can enter commercial export channels. This highmoisture grain is usually placed in special bins and shipped separately.

Each crop has its own particular storage characteristics and safe storage depends largely on its moisture content, its temperature, the length and time of storage, and other factors. By knowing the moisture content and temperature of a crop at binning it is possible to predict its future storability. In (Fig. 5), moisture-temperature combinations are shown for storage of canola, which result in either spoilage or no spoilage over 5 months. To move a crop from spoilage in the upper part of the chart to no spoilage below, either dry the commodity or cool it by aeration.

To store wheat safely for up to 6 months, temperature and moisture content combinations may be used for prediction (Fig. 6). 
Table 1 Percentage moisture content of tough or damp cereal grains, oilseeds, and legumes

\begin{tabular}{lcc}
\hline & \multicolumn{2}{c}{$\begin{array}{c}\text { Moisture content } \\
\text { (wet weight) }\end{array}$} \\
\cline { 2 - 3 } Crop & Tough(\%) & Damp(\%) \\
\hline Wheat & $14.6-17.0$ & $>17.0$ \\
Amber durum & $14.6-17.0$ & $>17.0$ \\
Buckwheat & $16.1-18.0$ & $>18.0$ \\
Oats & $14.1-17.0$ & $>17.0$ \\
Barley & $14.9-17.0$ & $>17.0$ \\
Flaxseed & $10.1-13.5$ & $>13.5$ \\
Canola (Rapeseed) & $10.1-12.5$ & $>12.5$ \\
Mustard seed & $10.6-12.5$ & $>17.5$ \\
Rye & $14.1-17.0$ & $>18.0$ \\
Peas & $16.1-18.0$ & $17.6-21.0$ \\
Corn & $15.6-17.5$ & $16.1-18.0$ \\
Soybeans & $14.1-16.0$ & $13.6-17.0$ \\
Sunflower & $9.6-13.5$ & \\
\end{tabular}

Source: Canadian Grain Commission 1989.

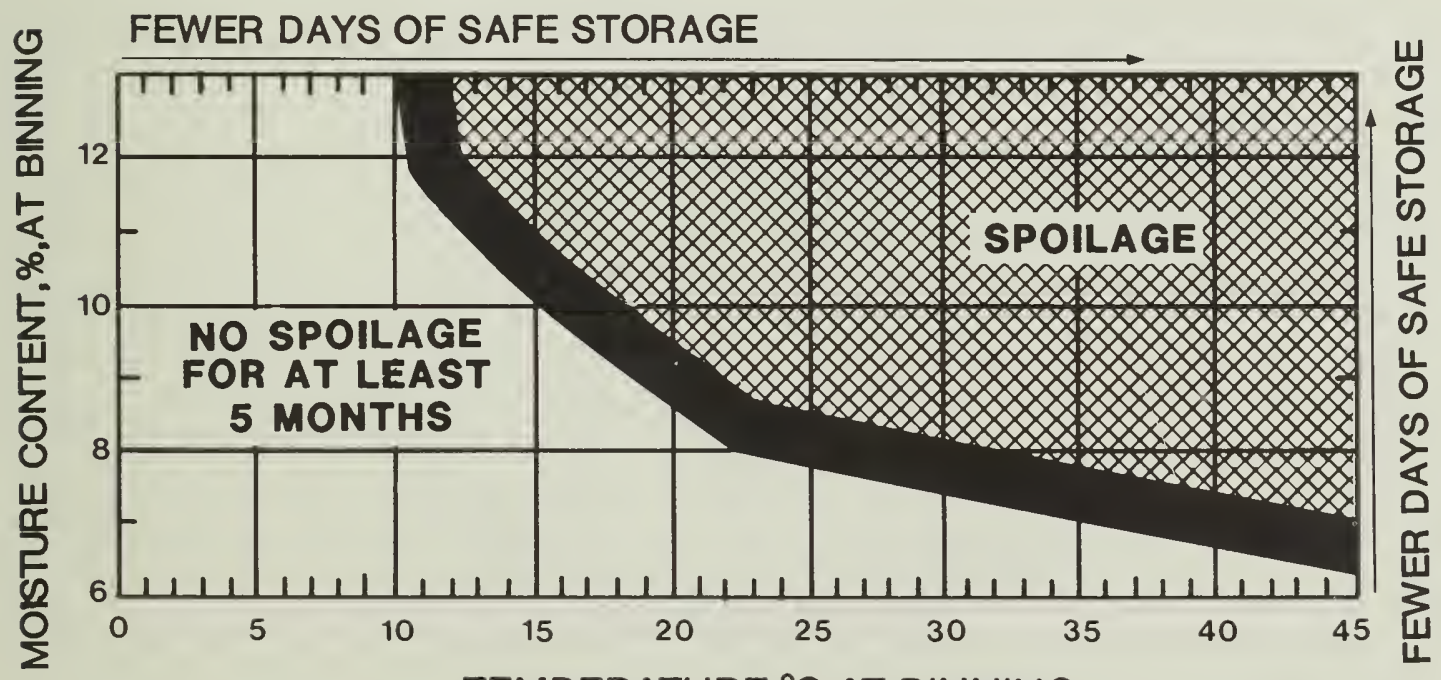

TEMPERATURE ${ }^{\circ} \mathrm{C}$ AT BINNING

Fig. 5 Canola storage time chart based on seed moisture and temperature at binning (from Canola Growers Manual. Ch.12 Storage and conditioning of canola. Canola Council of Canada). 


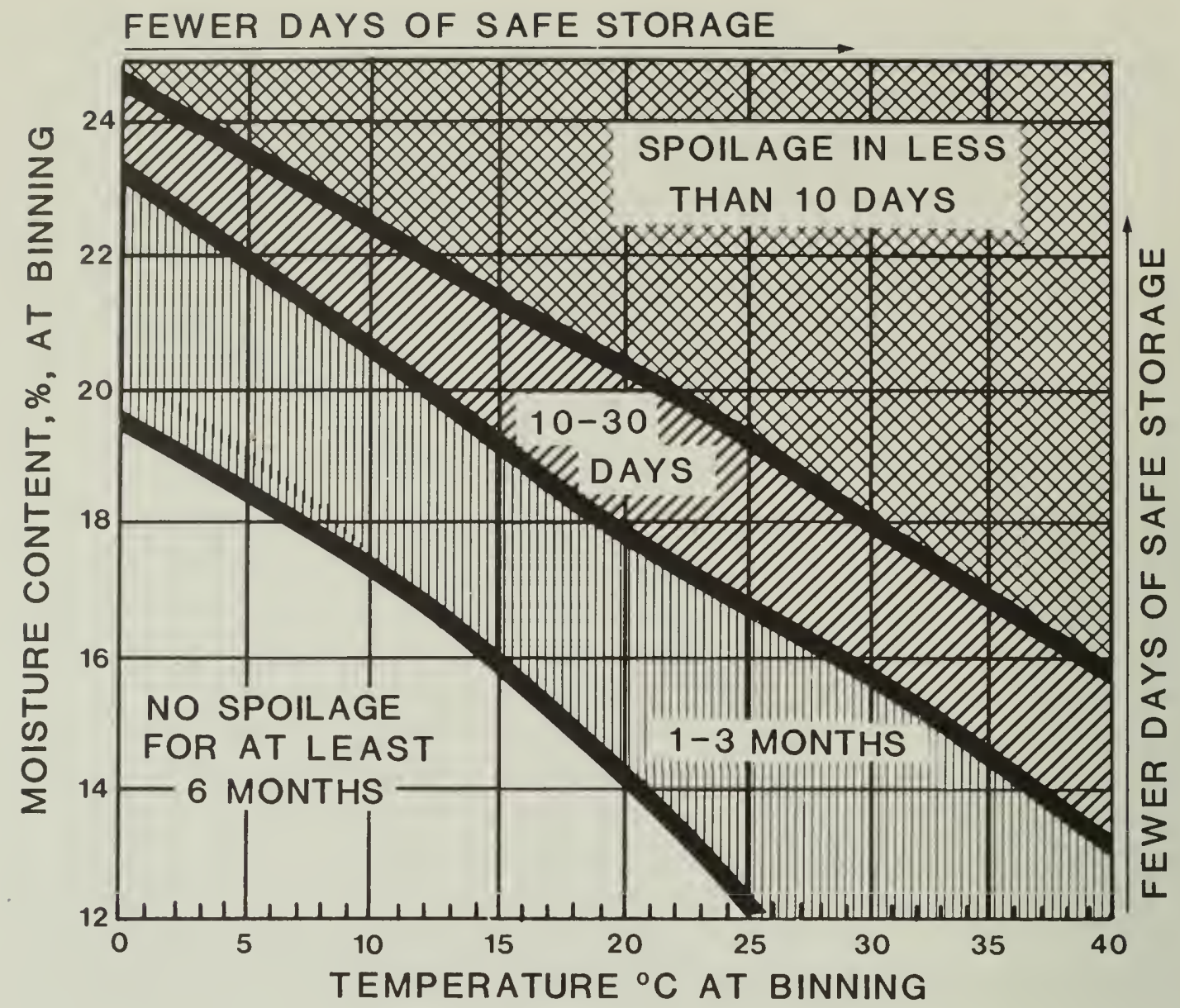

Fig. 6 Wheat storage time chart showing zones in which spoilage occurs in less than 10 days, within 10-30 days, within 1-3 months, and no spoilage for at least 6 months (from Wilkins 1983).

\section{BIN MONITORING}

\section{Need for monitoring}

Stored grains are living organisms. The economic value of grains in storage can drop rapidly when they are allowed to deteriorate. Successful in-bin drying requires daily monitoring of bulks and an understanding of the drying and spoilage processes. Thus to maintain the value of grains during storage, measure their moisture and temperature condition regularly, so that remedial action can be taken if it appears that they will spoil before drying takes place.

Monitoring of bulks can be done by entering the bins, observing the condition and odor of the surface grain, and, with a probe, removing samples from deep in the bulk. This activity can be timeconsuming, difficult, and dangerous and is therefore frequently neglected. Active spoilage is indicated by changes in temperatures or concentration of carbon dioxide, or both. 


\section{Bulk temperature}

The most common and readily available method of monitoring for spoilage is to measure temperatures throughout the bulk with permanently or temporarily installed electrical sensors (Fig. 7). One such system consists of a cable and a hand-held, battery-operated monitor. The cable hangs down the centre of the bin with temperature points every $1.2 \mathrm{~m}$ and down the outside of the bin with the connector at eye level. The monitor is plugged into the connector and the bulk temperatures are read off and recorded.
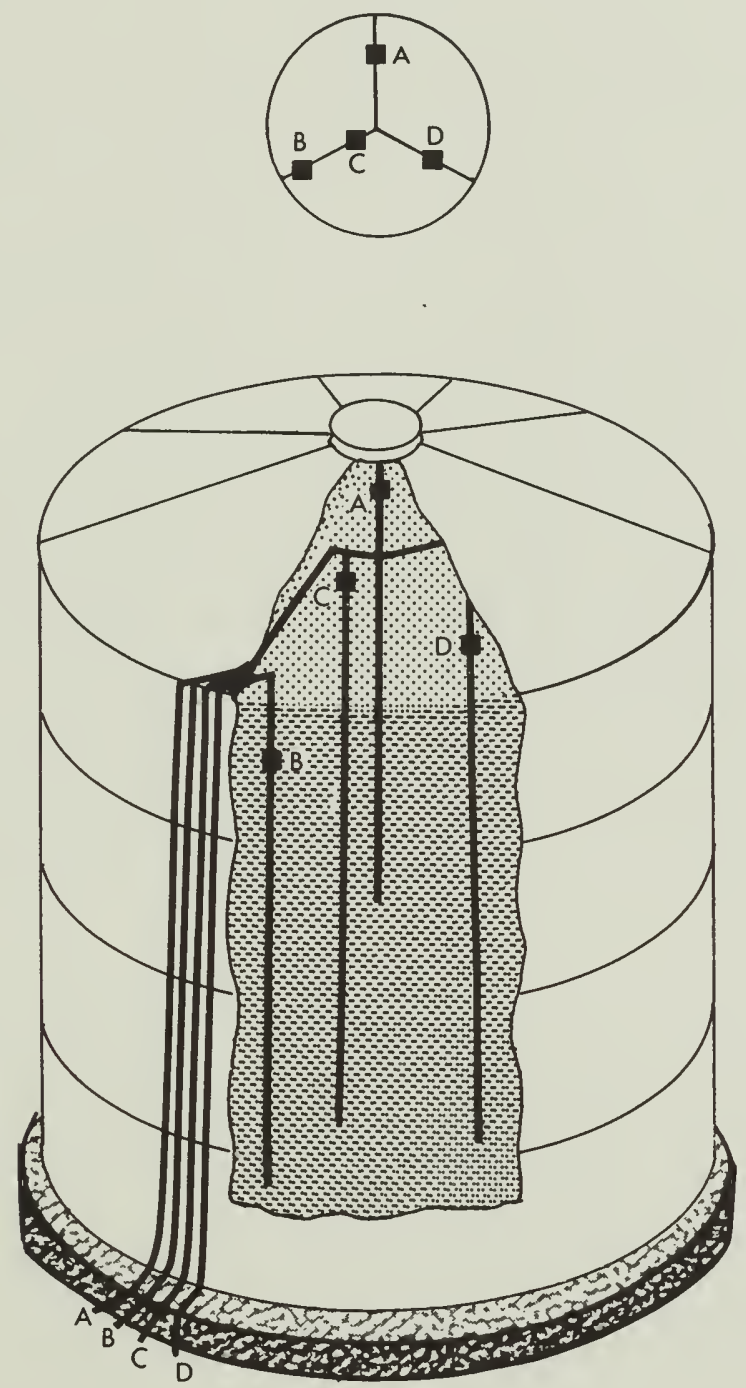

Fig. 7 Bin temperature monitoring system of four sensing cables A-D suspended from the roof. Cables $A, B$, and $D$ are located halfway between the wall and bin centre and $\mathrm{C}$ is located close to the centre. Note: Cables longer than 8-12 $\mathrm{m}$ require support brackets to prevent the roof being pulled down by the cables (McKenzie et al. 1980). The cables should be attached to the floor otherwise grain will push them sideways providing false readings. 
Measuring temperatures regularly throughout the bulk during aeration can locate the cooling front. Turn the fan off when the bulk temperature is cooled to the outside temperature and turn it on again when the outside temperature drops below the bulk temperature.

When grain spoils from the growth of molds or insects, oxygen is consumed while heat, carbon dioxide, and water are produced. The heat can cause the temperature of spoiling grain to rise. Thus in an unventilated bulk, temperature measurements may be useful in detecting deterioration. But difficulties arise in using and interpreting temperature results.

- Temperatures of large grain or oilseed bulks change slowly. For example at the centre of a 6-m diameter bin the temperature can be highest in winter and lowest in summer.

- When a small pocket of grain spoils the temperature at the centre of the pocket may reach $65^{\circ} \mathrm{C}$ whereas only $50 \mathrm{~cm}$ away the grain may be $10^{\circ} \mathrm{C}$. To detect small pockets, temperatures must be measured at many points or at least where spoilage is most probable.

- Low bulk temperatures do not necessarily indicate safe storage conditions. At $-5^{\circ} \mathrm{C}$, some molds can begin to grow slowly; above $10^{\circ} \mathrm{C}$ both molds and mites can flourish. Most insects, however, require bulk temperatures above $20^{\circ} \mathrm{C}$ to reproduce rapidly.

- Bulk temperatures above outside air temperatures do not necessarily indicate the occurrence of spoilage. Straight-grade crops can be harvested and placed into storage in excellent condition at warm temperatures. But, when the crop is harvested and stored on a hot day, insects flying in from outside and those from the walls and floor debris in an unclean bin may start an infestation by multiplying rapidly. Such grain should be cooled by turning or by aeration to prevent insects from breeding. If the crops are stored dry in large, unventilated storages the temperatures near the centre can remain relatively high throughout the cold winter months without any spoilage occurring.

\section{Carbon dioxide concentration}

A second method of detecting active spoilage caused by either molds or insects is to measure the concentration of carbon dioxide $\left(\mathrm{CO}_{2}\right)$ in the intergranular air. The usual biological deterioration process occurring in stored grain and oilseeds consumes oxygen and produces carbon dioxide. The concentration of $\mathrm{CO}_{2}$ in outside air is about $0.03-0.04 \%$ (300-400 ppm). Concentrations above this level in a bin indicate that biological activity (molds, insects, mites, or grain respiration) is causing the stored crop to deteriorate.

As $\mathrm{CO}_{2}$ usually moves away from the spoilage pockets to the surrounding bulk, gas sampling points need not be right in the spoilage pockets. But it is preferable to sample at locations where spoilage usually occurs, such as at the centre of the bulk about 1-2 m below the top surface. 


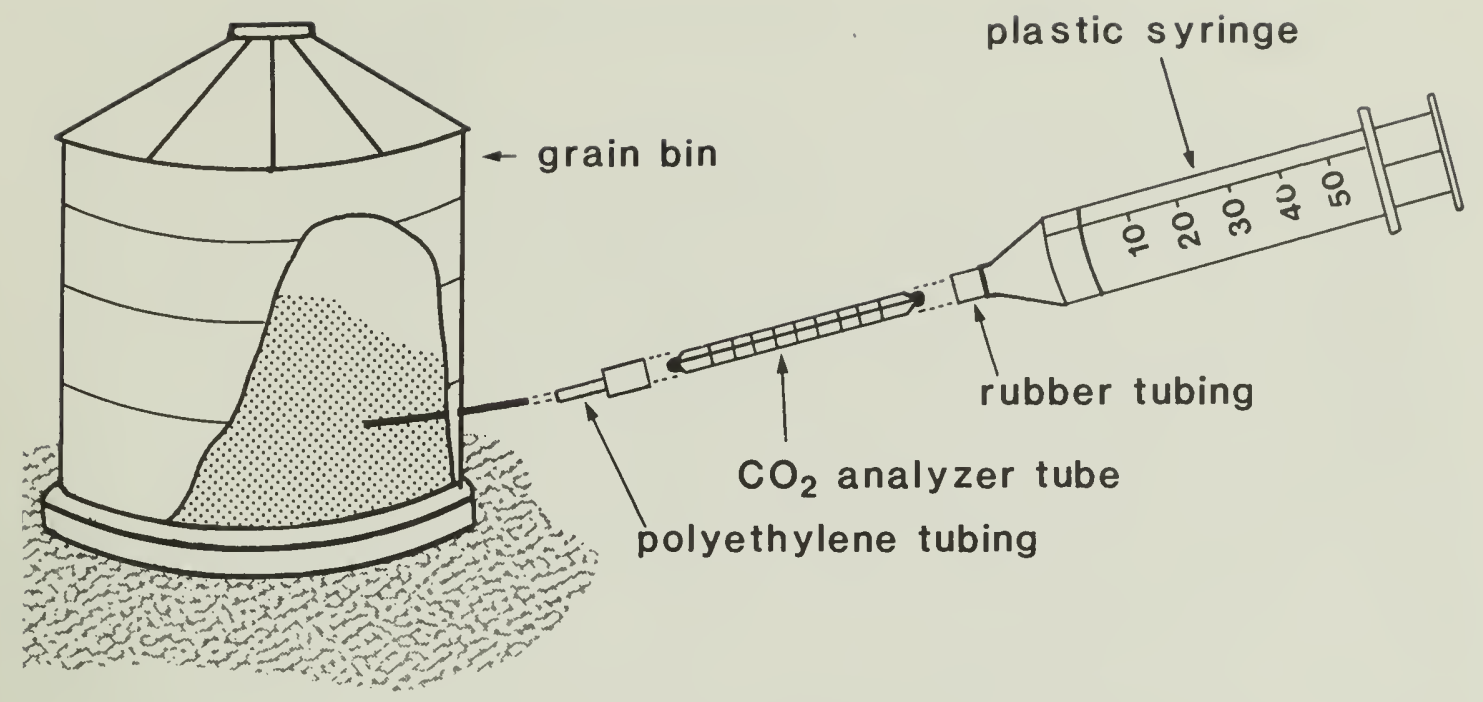

Fig. 8 Device for detecting grain and oilseed spoilage by carbon dioxide measurement.

Carbon dioxide sampling equipment

Air samples can be withdrawn through small-diameter plastic tubes temporarily or permanently located within the bulk, using a hand pump, syringe, or electric pump. The concentration of the $\mathrm{CO}_{2}$ can be measured with an electronic detector.

The other alternative is to use inexpensive, gas-analyzer tubes, which change color according to the amount of $\mathrm{CO}_{2}$ passed through them. The tubes can only be used once. Tubes cost in the range of $\$ 1.50-4.00$ each (in 1989) and can be obtained from most safety equipment outlets (Fig. 8).

\section{IDENTIFYING THE ORGANISMS}

\section{COMMON STORED-PRODUCT PESTS}

Of more than 100 species of stored-product insects and mites found across Canada, only a few cause serious damage; the others are fungus feeders, scavengers, predators, and parasites.

Beetles and moths, the most-common stored-product insect pests, have four life stages: egg, larva, pupa, and adult (Fig. 9). Booklice (psocids) and mites have only egg, nymph, and adult stages.

Eggs The eggs may be laid either in the crevices of kernels or in the dust and refuse within bins. Some species, such as granary weevils, lay their eggs inside kernels. 

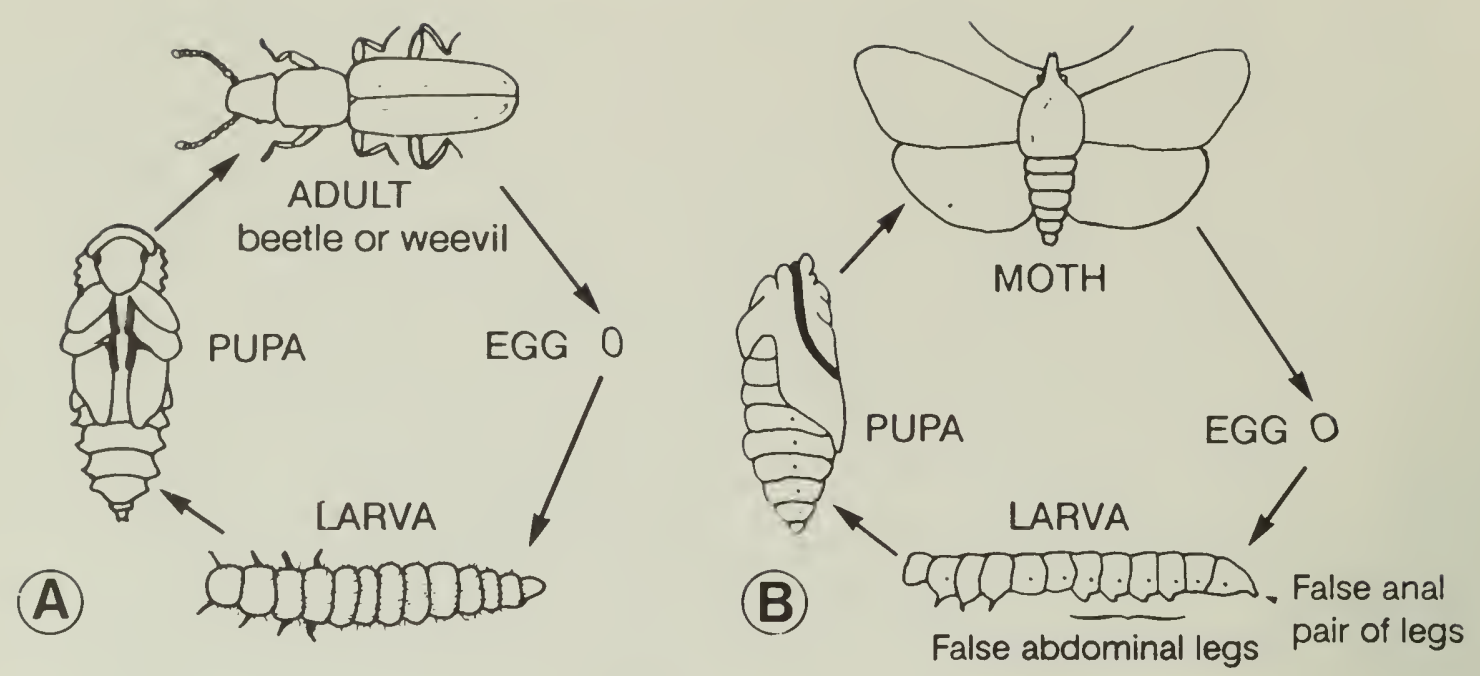

Fig. 9 Life cycles of stored-product insects: $A$, a beetle and $B$, a moth (from Scotti 1978).

Larva The larva is the only stage during which the insect grows. It consumes several times its own weight in food, and, as the larval skin cannot stretch, it periodically molts allowing it to increase in size. Cast-off skins found in grains and oilseeds and their products indicate that insects are, or were, present.

Pupa The pupa, which forms after the last larval molt, does not feed. In some species, the pupa is enclosed in a cell, or cocoon, constructed by the larva. During the pupal stage, the insect undergoes extreme internal and external changes that lead to the development of the adult.

Adults Adults of stored-product insects are between 0.1 and $1.2 \mathrm{~cm}$ long. They have three pairs of legs and their bodies are divided into three parts: head, thorax, and abdomen. The head includes the mouthparts and sense organs; the thorax bears the legs and wings; and the abdomen contains the reproductive organs. Adults move in the spaces between kernels and can penetrate deeply into a pile of grains or oilseeds, with the exception of moths and spider beetles. Some stored-product insects can fly and are widely distributed. Beetles have poorly developed wings and some species are unable to fly, although the rusty grain beetle and the red flour beetle can fly well.

\section{Beetles}

Stored-product beetles often appear similar but have differing behavior patterns and status as pests. It is important to determine which species are present before taking remedial action. A detailed identification guide is now available (Bousquet 1990) to help determine which species are present. The characteristic features of 
the main beetle species occurring on stored grains and oilseed crops in Canada are as follows.

Rusty grain beetle This beetle (Plate I $a, b$ ) is the most serious pest of stored grain in most regions of Canada. It usually feeds on the germ (embryo) part of a whole seed. Heavy infestations cause grain to spoil and heat. The adult is a flat, rectangular, shiny, reddish-brown beetle, $0.2 \mathrm{~cm}$ long and has long, bead-shaped antennae that project forward in a V. It moves rapidly in warm grain and can fly when air temperature is above $23^{\circ} \mathrm{C}$. Eggs are laid in the crevices of kernels and in grain dust. The tiny larvae penetrate and feed on the germ of damaged kernels. Eggs become adults in wheat in about 21 days at $14.5 \%$ moisture content and $31^{\circ} \mathrm{C}$.

Flat grain beetle This insect is similar in appearance and feeding habits to the rusty grain beetle except that the males have longer antennae. It is an important pest of stored grain in the northern United States and is now appearing in grain bins in southern parts of the Canadian prairies.

Red flour beetle This pest (Plate IIc, $d$ ) develops on stored grains and oilseeds on farms and in primary elevators throughout the Prairie Provinces and most of Canada. The adult is reddish brown and $0.4 \mathrm{~cm}$ long. Larvae and adults feed on broken kernels. Complete development from egg to adult occurs in about 28 days under optimal conditions of $31^{\circ} \mathrm{C}$ and $15 \%$ moisture content. Slower development occurs at moisture contents as low as $8 \%$. Adults fly in warm weather or may be blown by the wind into farmhouses or other buildings.

Confused flour beetle The adult (Plate IIe) resembles that of the red flour beetle and is difficult to distinguish without a microscope or magnifying glass. Larvae and adults feed on flour, feed, and other ground material. Unlike the red flour beetle, the confused flour beetle is more common in flour mills than elsewhere, and the adults do not fly.

American black flour beetle This beetle is similar to, and larger than, the red flour beetle but black in color. It is commonly found in empty granaries but rarely infests farm-stored grains and oilseeds in large numbers.

Fungus beetles These pests usually infest tough or damp grains and oilseeds and feed on associated dust and molds. Dry seed bulks stored next to tough or damp seed bulks may also become infested. The foreign grain beetle, the squarenosed fungus beetle, and the sigmoid fungus beetle are the most common fungus-feeding insects found in stored grain and oilseed crops. Because certain species of fungus beetles resemble the rusty grain beetle and are about the same size, apply chemical control measures only after the insects are correctly identified. 

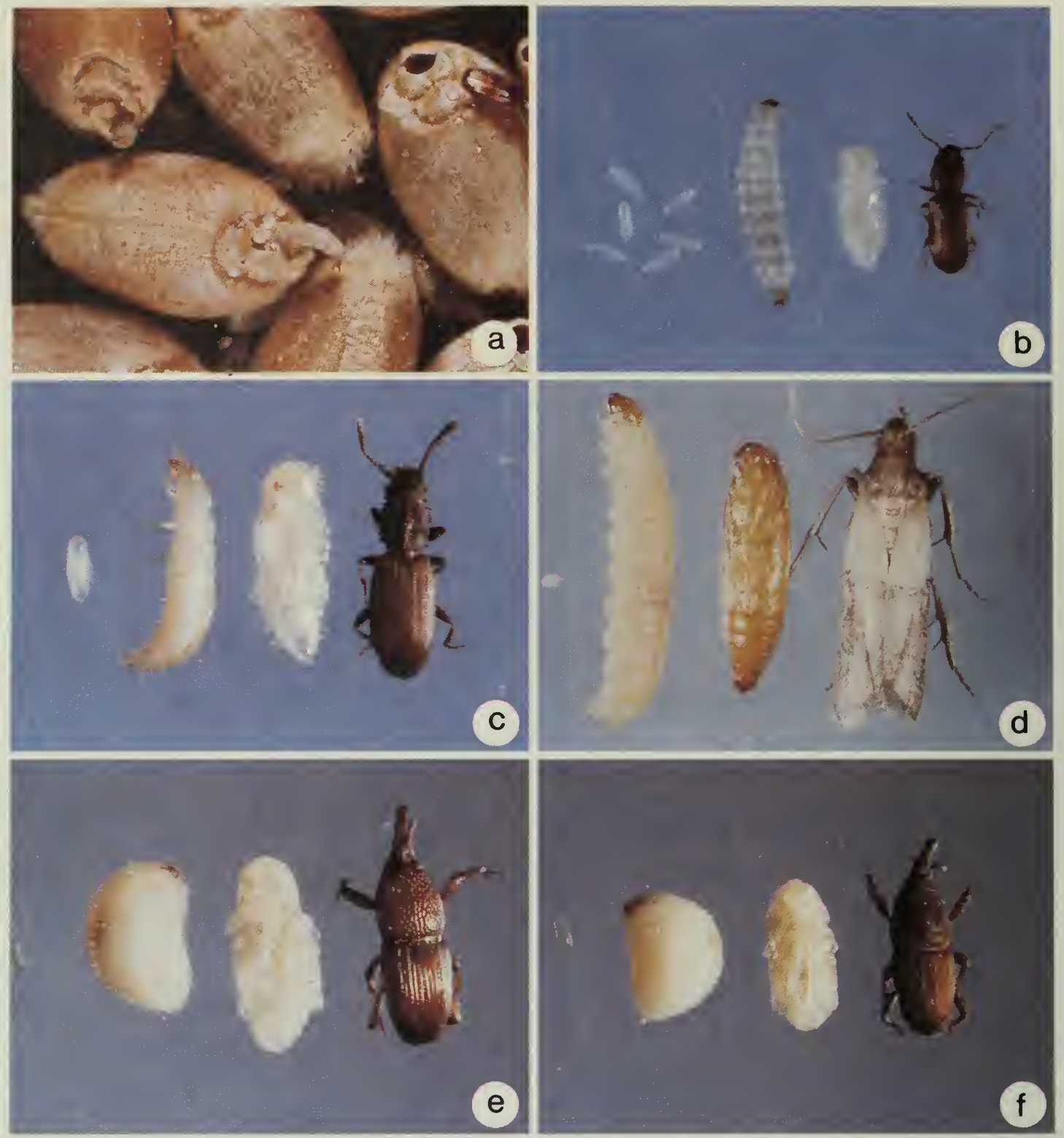

Plate I $a$ Wheat kernels infested by rusty grain beetles.

$b$ Life stages of the rusty grain beetle (left to right): eggs, larva, pupa, and adult.

c Life stages of the sawtoothed grain beetle (left to right): eggs, larva, pupa, and adult.

$d$ Life stages of the Indianmeal moth (left to right): eggs, larva, pupa, and adult.

$e$ Life stages of the granary weevil (left to right): eggs, larva, pupa, and adult.

$f$ Life stages of the rice weevil (left to right): eggs, larva, pupa, and adult. (From Sinha and Watters 1985.) 

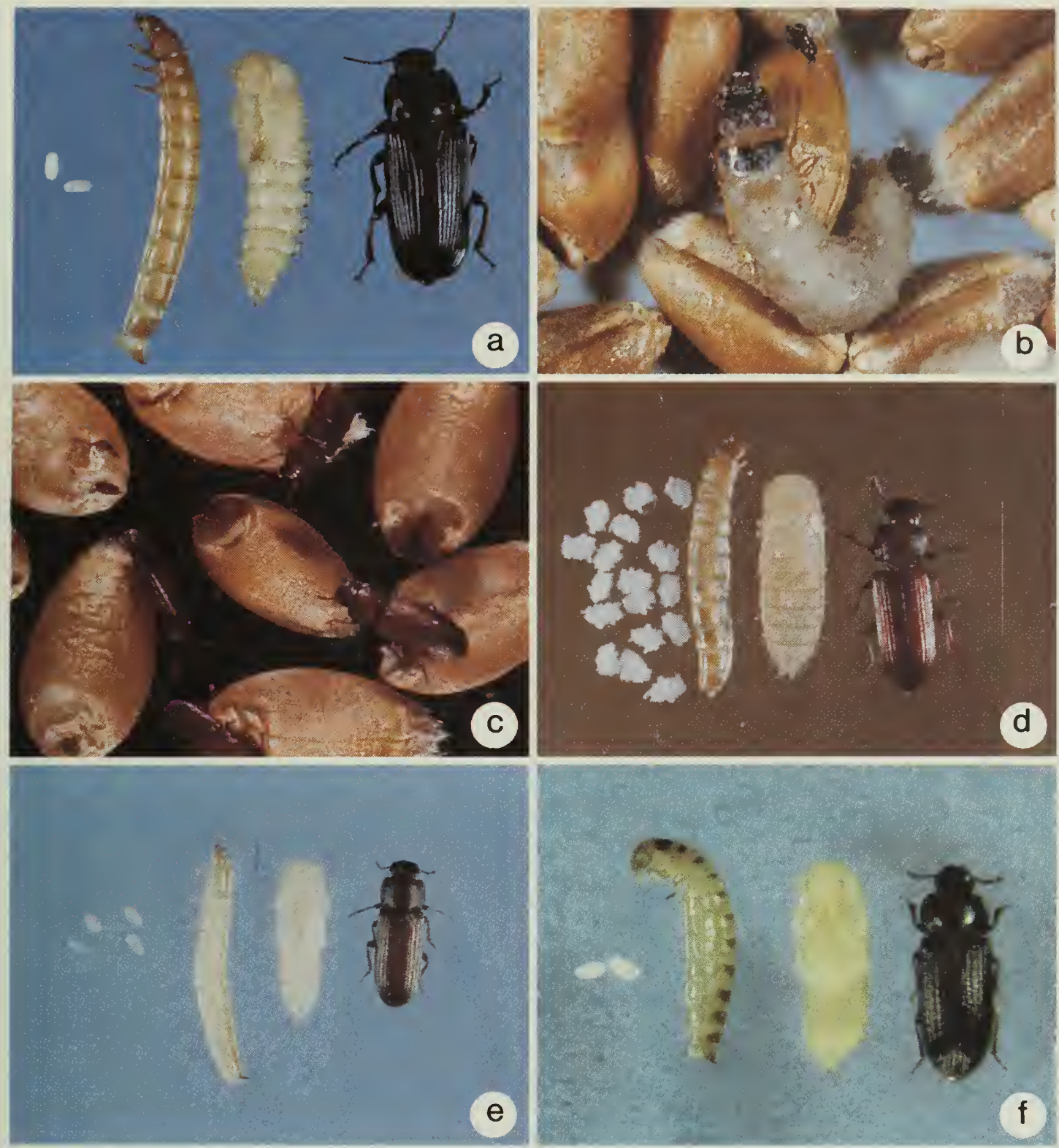

Plate II $a$ Life stages of the yellow mealworm (left to right): eggs, larva, pupa, and adult.

$b$ Larva of the cadelle on wheat kernels.

$c$ Wheat kernels infested by red flour beetle adults.

$d$ Life stages of the red flour beetle (left to right): eggs, larva, pupa, and adult.

$e$ Life stages of the confused flour beetle (left to right): eggs, larva, pupa, and adult.

$f$ Life stages of the European black flour beetle (left to right): eggs, larva, pupa, and adult.

(From Sinha and Watters 1985.) 
Fungus beetles in stored grains and oilseeds are cause for as much concern as are rusty grain beetles, because they indicate that high moisture and molds are present and that the crop may be going out of condition. The grains or oilseeds must be turned and dried to break up tough or damp pockets. As fumigation will not stop spoilage by molds or heating, take measures to move the bulk immediately, or it may spoil resulting in significant losses.

Sawtoothed grain beetles These beetles (Plate Ic) are more common in oats than in wheat, barley, or canola, particularly in southern Ontario and Quebec. The adult is brown, is about $0.3 \mathrm{~cm}$ long, and has six toothlike projections on each side of the thorax. In warm grain it takes about 22 days to develop from egg to adult under optimal conditions of $31-34^{\circ} \mathrm{C}$ and $14-15 \%$ moisture content.

Granary weevil This weevil (Plate Ie) is one of the most destructive pests of stored grain in the world. It is scarce in the prairies but occurs in Ontario. The adults have a distinctive snout, with which they bore into grain kernels. The female deposits a single egg in a hole in each kernel and then seals the opening with a gelatinous plug. The larvae feed on the endosperm and complete their development within the kernel. The pupae develop into adults that chew holes in the side of the kernels as they emerge. Development from egg to adult takes 2535 days under optimal conditions of $26-30^{\circ} \mathrm{C}$ and $14 \%$ moisture content. The granary weevil adult is about $0.3-0.4 \mathrm{~cm}$ long and cannot fly. When disturbed, they fold their legs under their body and appear to be dead.

Rice weevil This weevil (Plate If) has been found in southwestern Ontario storages and in some prairie elevators in recent years. It is $0.2-0.4 \mathrm{~cm}$ long and has four distinct reddish orange spots on the wing covers, which are folded over the abdomen. It completes development from egg to adult in 28 days at $30^{\circ} \mathrm{C}$ and $14 \%$ moisture content. Adult rice weevils can fly.

Hairy spider beetle This beetle is mainly a pest of wheat flour and animal feeds but may also infest stored grain near the surface. Adults and larvae have strong jaws, which they use to chew large, irregular holes in the endosperm of kernels. The adult is $0.35 \mathrm{~cm}$ long and has long, spiderlike legs and long, thin antennae. This beetle has only one generation a year. Three or four larvae often cement five to eight kernels together to form a cluster, where they feed and grow for up to 5 months; then each constructs its own pupal cell, from which the adult emerges. 
Yellow mealworms These insects (Plate II $a$ ) are the largest found in stored grain. They are not common pests on farms. They first infest animal feeds and then move into stored grain that is going out of condition. The adults are black beetles about $1.5 \mathrm{~cm}$ long; the larvae are yellow and $0.2-2.8 \mathrm{~cm}$ long. Yellow mealworms prefer dark, damp places in a granary or a feed bin. The adults live for several months and the larvae may take 1-2 years to change into pupae under harsh conditions. Because of their relatively large size, they are easily visible and often appear to be more numerous than they actually are. Their presence indicates poor storage conditions.

\section{Psocids (booklice)}

These insects are slightly larger than grain mites. The adult is soft-bodied and about $1.0 \mathrm{~mm}$ long. It has a large head and long antennae, and some species have wings and may be confused with small flies (Fig. 10C). The female lays about 100 eggs in 3 weeks, which develop into adults during the summer. The egg develops through nymph to adult in about 21 days at $27^{\circ} \mathrm{C}$ and $13 \%$ moisture content; some adults can live for 51 days without feeding In most
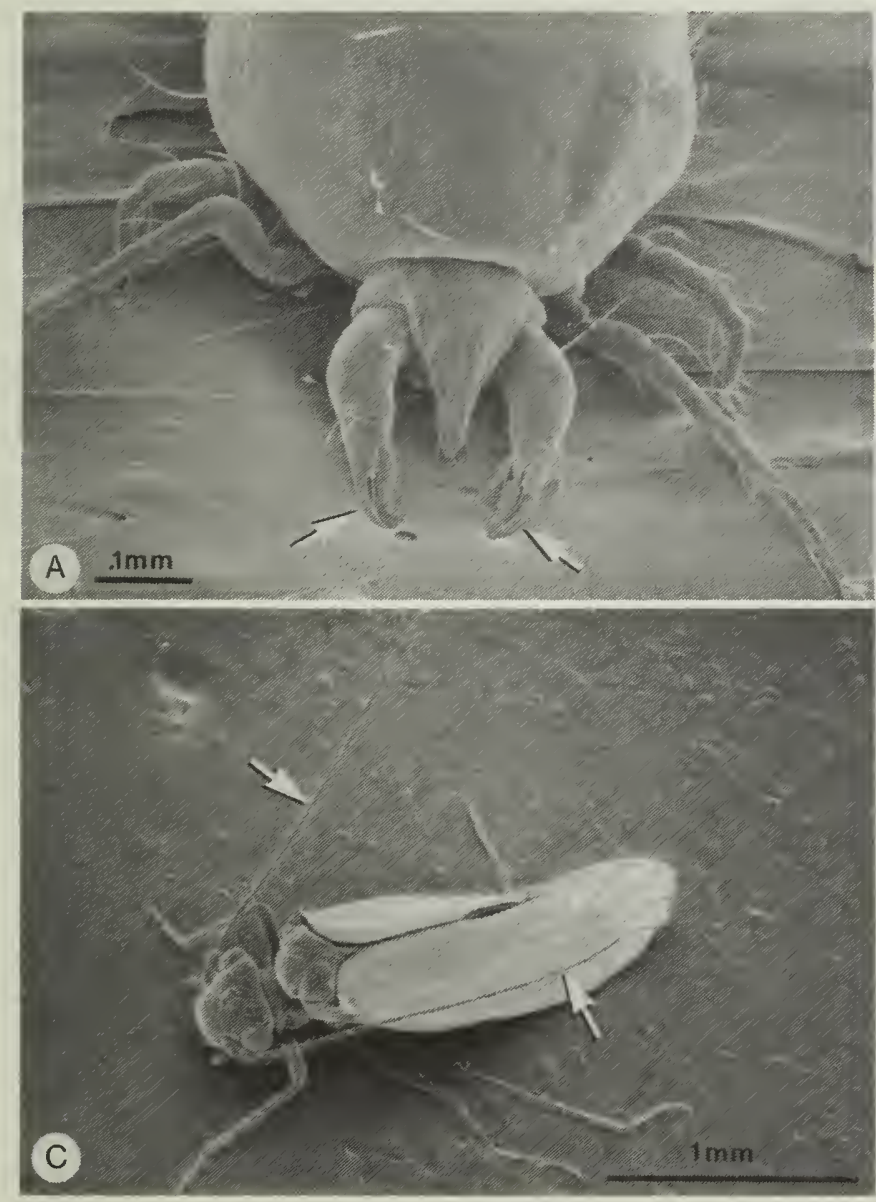

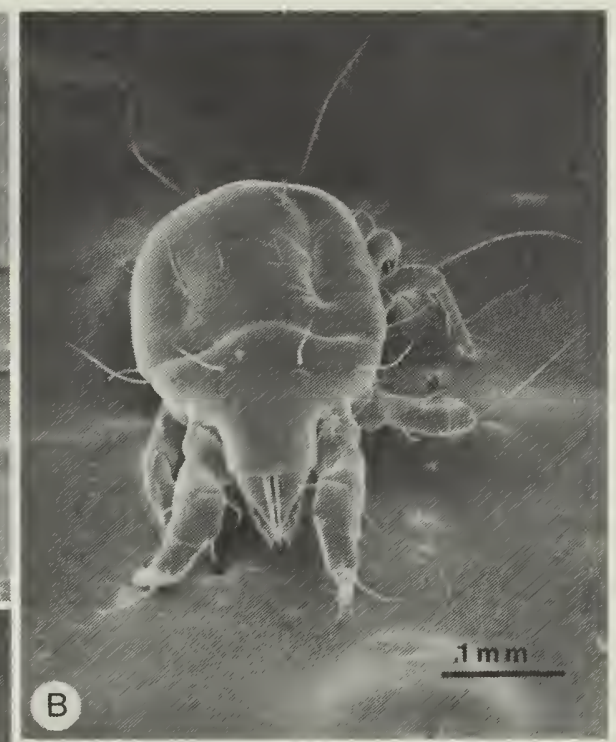

Fig. 10 Scanning electron microscope views: $A$, cannibal mite with large holding mouthparts (arrows); $B$, grain mite; and $C$, winged psocid with long antennae (arrows). 
years psocids cause no major problems, although they can feed on damaged kernels and are found in tough or damp grain. Occasionally, they occur in large numbers in widespread areas without any warning but do not cause serious damage to the stored crops. They are usually found with other insects or mites that are more serious pests of stored grains and oilseeds, often feeding on their eggs.

\section{Moths}

These pests are common in central Canada and on the east and west coasts. Adult moths do not feed, but their larvae have strong mouthparts and cause extensive surface damage to stored grain. Low winter temperatures usually control moth infestations, which are confined mainly to the surface layers of tough or damp grains that may be heating.

Meal moths These moths (Plate III $b, c$ ) are moderately cold-hardy and can overwinter and thrive during warm months in unheated farm granaries across the Prairie Provinces. They usually occur in patches of moist, moldy grain. The larvae are cream-colored, have black heads, and are about $2 \mathrm{~cm}$ long when full-grown. They produce a silklike substance that webs the kernels together in clumps. The moth has a wingspread of $2.5 \mathrm{~cm}$. The fore wings are light brown, with dark brown patches at the bases and tips. Each wing has two wavy, white stripes. The life cycle takes about 2 months to complete in summer.

Indianmeal moths These moths (Plate Id) are common in central Canada primarily on corn and processed feeds and foods.

Brown house moths, whiteshouldered house moths, and Mediterranean flour moths These moths (Plate III $a$ ) commonly occur in grain on the east and west coasts.

\section{Mites}

Mites are the smallest of the stored-product pests. They are common in grain stored at 14-17\% moisture content but, because of their microscopic size, often go unnoticed. Mites, belonging to the same class as spiders and centipedes, are fragile creatures that are hard to see with the naked eye (Figs. 10,11). Unlike an adult insect, which has a distinct head, thorax, abdomen, and six legs, an adult mite has a saclike body with eight legs; a larva has six legs. Mites are cold-hardy; most feed on broken grain, weed seeds, dockage, and molds. They are therefore well adapted for infesting stored products. Some mites, such as the cannibal mite, feed on their own members, other mites, or insect eggs. They breed in tough and damp pockets of cereals and canola. About $25 \%$ of such seed in a bulk may be infested 

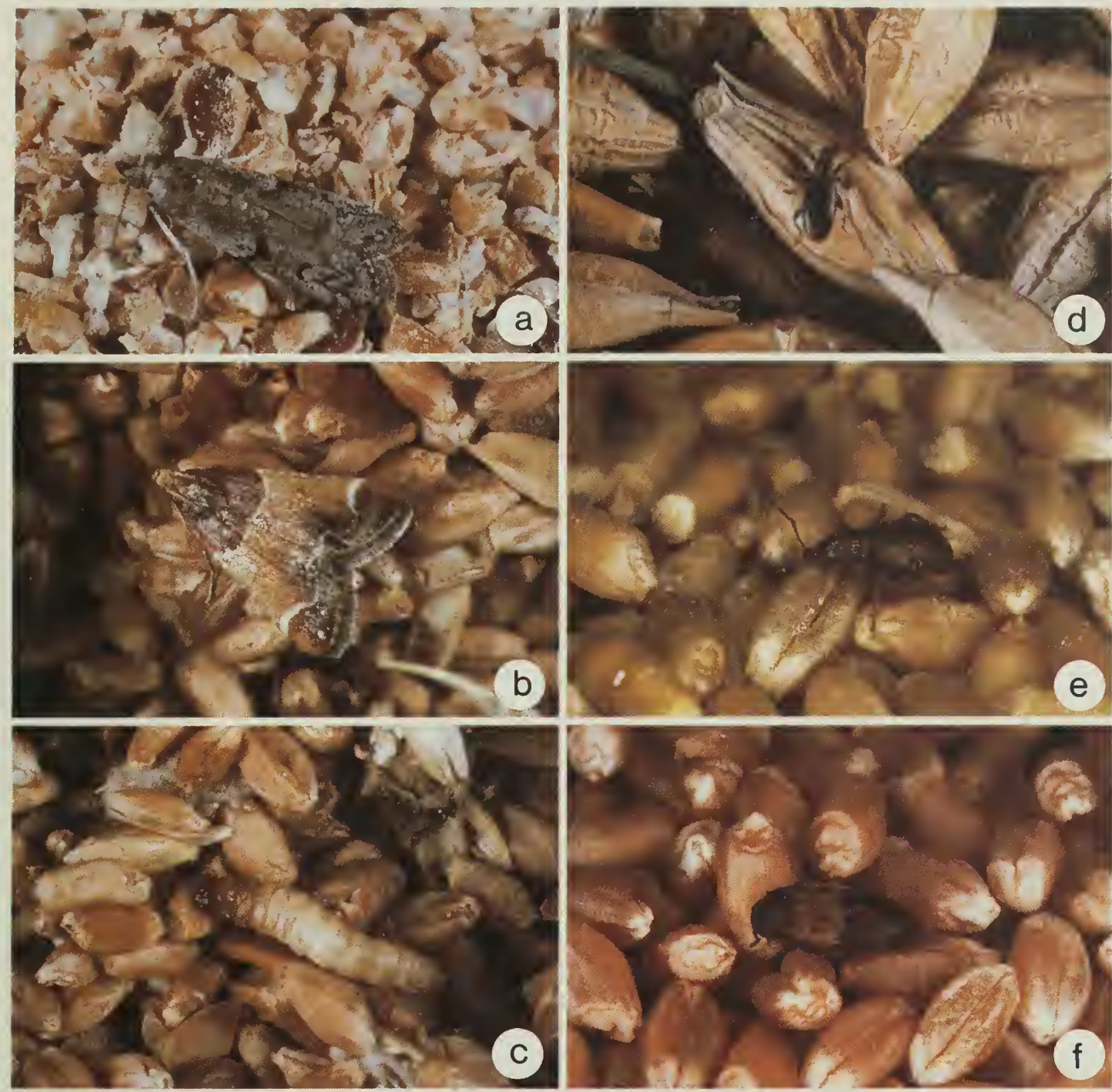

Plate III Some pest $(a-c)$ and nonpest ( $d-f$ ) insects of grains and oilseeds:

$a$, Mediterranean flour moth; $b$, meal moth (adult); $c$, meal moth (larva); $d$, antlike flower beetle; $e$, strawberry root weevil; and $f$, Dermestid beetle (courtesy of Lloyd Harris, Saskatchewan Agriculture, Regina, Sask.). 
with mites. About eight kinds of mites are common in farm granaries and elevators. Some give a strong, minty odor to infested grains and oilseeds. Their life cycle is composed of the egg stage, the six-legged larval stage, two or three eight-legged nymphal stages, and the eightlegged adult stage. Some mites change into a nonfeeding developmental stage called hypopi during which they become resistant to low winter temperatures, drying, starvation, and most fumigants; they may be mobile or inactive. This stage can last for prolonged periods until developmental conditions improve.

Grain mite This mite (Figs. 10B, 11A) attacks the germ (embryo) of seeds, which reduces germination, and spreads fungi (molds), which are also eaten. Heavily infested grain becomes tainted and unpalatable as animal feed. In some cases, dairy cattle and other farm animals develop gastric disorders and other symptoms after eating mite-infested feed. Adults are 0.3-0.6 mm long and females are larger than males. This mite is pearly white to yellow brown and has a smooth, glistening body with four long hairs arising from the rear end. Grain mite populations can increase up to sevenfold in 1 week in stored grains and oilseeds, particularly during the fall. Adult females can lay about 500 eggs during a lifespan of 42 days. The grain mite can develop from egg to adult in 14 days at $20^{\circ} \mathrm{C}$ and $14 \%$ moisture content. Adults and all immature stages except the nonfeeding developmental stage die in about 1 week when exposed to $-18^{\circ} \mathrm{C}$. Eggs can survive exposure to $-10^{\circ} \mathrm{C}$ for about 12 days or $0^{\circ} \mathrm{C}$ for $2-3$ months.

Longhaired mite This species (Fig. 11D) is the most common storedproduct mite. It is cold-hardy and can live in both straight-grade and tough grains and oilseeds. It moves rapidly with a jerky gait and feeds on broken grain, grain dust, and fungi. The adult is white and about $0.3-0.5 \mathrm{~mm}$ long and has many stiff hairs that are longer than its body. In farm granaries, chronic infestations of this mite generally occur between June and November. It can survive for more than 7 days at $-18^{\circ} \mathrm{C}$.

Cannibal mite As the name suggests, this mite (Fig. 10A) feeds on its own kind, and also on the grain mite, the longhaired mite, and insect eggs and larvae. Because cannibal mites are not abundant enough to eliminate the mite pests that damage grains or oilseeds they are not very useful for biological control of grain feeding mites. They have a diamond-shaped, white body with a chalky white line running the length of the body, pincerlike grasping appendages near the mouth, and long legs. They are $0.4-0.6 \mathrm{~mm}$ long. Cannibal mites are active in bulk grain in all seasons, usually in low numbers. In most tough grains and oilseeds they can breed between 12 and $27^{\circ} \mathrm{C}$.

Glossy grain mite This mite (Figs. $11 E, F$ ) is a common fungus-feeder found in aging farm-stored grains and oilseeds. It develops from the egg to adult stage in 7 days under optimal conditions of $30^{\circ} \mathrm{C}$ and $17 \%$ 

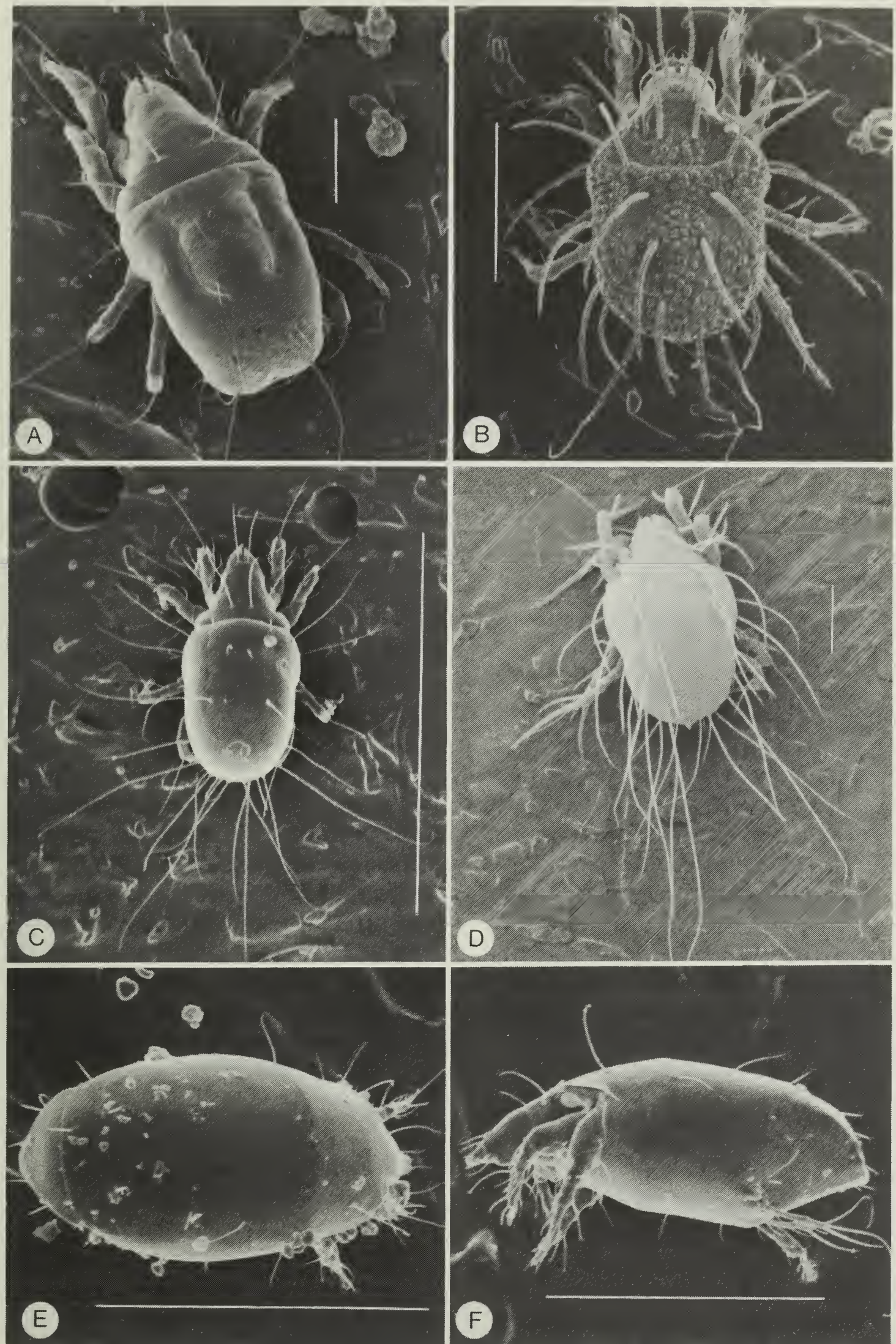

Fig. 11 Some major stored product mites as viewed by scanning electron microscope: $A$, the grain mite; $B$, warty grain mite; $C$, mold mite; $D$, longhaired mite; $E$, glossy grain mite female viewed from above; and $F$, glossy grain mite female viewed from the side. (Magnification is shown by the bar on each photograph, which represents $0.1 \mathrm{~mm}$.) 
moisture content. The mite feeds on certain molds so its presence indicates that grain is becoming moldy and going out of condition. The adult is clear orange or yellowish and less than $0.2 \mathrm{~mm}$ long. It can live for about 17 days at $30^{\circ} \mathrm{C}$ and $90 \%$ relative humidity.

\section{STORAGE FUNGI}

These organisms, occurring mainly as spores in the soil and on decaying plant material, contaminate grains and oilseeds with low numbers of spores during harvesting.

Storage fungi are usually inactive at low grain-moisture levels. However, when the moisture is higher, as in tough, damp, or accidentally wetted grain, the spores germinate. Several species of Aspergillus and Penicillium are found on grains. Each fungal species requires a specific moisture and temperature level for germination and development and develops in a definite sequence. The first fungus to develop breaks down nutrients in the seed through its enzymatic activity and produces moisture, which allows other fungi to germinate in their turn.

Development of storage fungi on grains and oilseeds may affect their quality by causing heating and spoilage, packing or caking, reduced germination, and production of off-odors and mycotoxins. For further information on molds and their effects on stored products, consult Spoilage and heating of stored agricultural products. Prevention, detection, and control (Mills 1989).

\section{MYCOTOXINS}

Mycotoxins are fungal products that are poisonous to most farm animals and humans. Aspergillus and Penicillium growing on stored grains and oilseeds produce mycotoxins under favorable conditions of temperature and moisture. Mycotoxins have occasionally been found in areas of Canada where high humidity prevails.

When they occur, highly toxic mycotoxins are usually present at low concentrations detectable only by lengthy and complex chemical analyses. The health of farm animals can be affected at the parts per million level, or less. Animals feeding on moldy grain and feeds may show reduced mobility and productivity or, in extreme cases, may die. Farmers suspecting mycotoxin poisoning should consult their local veterinarian.

Stored grains and oilseeds often become contaminated with bluegreen Penicillium molds and Aspergillus versicolor through accidental dampening or faulty storage, and mycotoxin-producing strains of these fungi may develop. Contamination by the mycotoxins ochratoxin A, citrinin, and sterigmatocystin has been observed in crops stored damp and, from limited experimental information, appears to follow a specific risk pattern: 
- low risk: oats, HY320 wheat, hard red spring wheat, 2-row barley

- moderate risk: corn, 6-row barley

- high risk: amber durum wheat.

During periods of high rainfall, field fungi of the Fusarium type have infected standing wheat, giving rise to the development of a disease called fusarium head blight, which can produce low levels of trichothecene mycotoxins. It is not advisable to feed grain that is suspected of being contaminated by mycotoxins to animals, especially swine and poultry. For further information on feeding moldy grains to livestock consult Reducing mycotoxins in animal feeds (Trenholm et al. 1988).

\section{CONTROLLING INFESTATIONS}

To keep infestations from spreading to other granaries, pests should be controlled as soon as they are discovered. The type of control implemented will depend on the condition of the grain, bulk temperature, kinds of insects or mites present, and the time of year.

\section{COOLING AND CLEANING THE PRODUCT}

An effective method to control insect infestations in winter is to lower the temperature of the grain in the centre of the bin either by mixing and transferring infested crops from one granary to another; or by transferring part of the crop to a truck or a small pile exposed to low air temperatures, leaving it to cool for one or more days and then returning it to the granary; or by using aeration systems to lower the temperature. Insects do not develop or feed at temperatures below $10^{\circ} \mathrm{C}$. At temperatures below $0^{\circ} \mathrm{C}$, the insects will die eventually. Control of the rusty grain beetle will be obtained:

- after 2 weeks at a bulk temperature of $-15^{\circ} \mathrm{C}$

- after 6 weeks at a bulk temperature of $-10^{\circ} \mathrm{C}$

- after 8 weeks at a bulk temperature of $-5^{\circ} \mathrm{C}$.

As the rusty grain beetle is the species most resistant to low temperature, most other insects in stored grains and oilseeds will also be controlled by these combinations of temperature and exposure periods. Low temperatures do not kill fungi or all mites.

Cleaning the grain also checks infestations. To control surface infestation of moths, mites, and spider beetles, remove and destroy webbed and infested patches, rake the bulk surface to break up any crust, and thein dry the bulk. 


\section{TREATING WITH INSECTICIDES}

Warning Resistance to insecticide is becoming more common in stored-product insects across Canada notably in the Indianmeal moth in central Canada and in the red flour beetle, confused flour beetle, and rusty grain beetle throughout most of the country. Repeated use of one kind of insecticide in the same storage area increases the chance of development of insecticide resistance on the part of an insect pest. Thus use more than one control and prevention method, and use insecticide only when it is absolutely necessary.

To control insects occurring in residues in empty granaries, use only an insecticide that has been approved for use in granaries, and take precautions in its handling and use. Approved insecticides are selected largely on the basis of the following:

- low toxicity to mammals and high toxicity to insects

- freedom from taint or odor on food

- nonpersistent environmental effects

- safe, economical, and easy use

- presence of negligible residues or toxic products in food.

Some insecticides are more effective and longer lasting than others. Premium-grade malathion is at present the insecticide registered for empty-bin treatments and long-term protection of stored products. Pyrethrins with piperonyl butoxide are also registered for empty-bin treatments.

As insecticide sprays and dusts act only on contact with insects and do not penetrate piles of grain or dust on floors, remove residues from the granary before applying the insecticide.

Dissolve emulsifiable concentrates of malathion in clean water to form a milky emulsion and spray it on metal and wood surfaces immediately after mixing to avoid the insecticide separating from the water. Emulsifiable concentrates break down more rapidly, and are less effective, on concrete and brick surfaces than on wood or steel. Most insecticides break down within a few days on concrete but can remain effective for up to a year on wood or steel. Do not use these sprays near electrical switches or fuse boxes.

Wettable powder sprays can be applied to concrete, brick, metal, or wood surfaces (Fig. 12B). Mix wettable powder formulations of malathion with clean water in a separate container before filling the sprayer. Wettable powders applied on painted surfaces leave white specks.

In cold weather, oil solutions of insecticides are better than waterbased sprays because they will not freeze. Oil solutions can be prepared by mixing insecticide in deodorized kerosene following label instructions and can be used near electrical switches. Wood or metal surfaces can be sprayed and empty bins fogged, but avoid treating plastic or rubber surfaces with oil solutions. 
Insects beneath the floor or within wall spaces may be controlled with insecticide powders or dusts, because these places are hard to treat with liquid insecticides. These powders or dusts are usually commercial formulations of malathion on treated wheat flour. Use a dust applicator or sweep the dust into cracks in the floor.

Oilseeds absorb contact insecticides from treated granary surfaces. Therefore, avoid treating granaries in which oilseeds are to be stored. If the granary is infested, sweep it well, destroy the sweepings, and treat sparingly only the junctions of the floor and walls.

If stored-product insects are visible on the outside wall of the granary, spray the walls and surrounding ground. Even if insects are not readily visible, it is a sound practice to spray not only grain spillage, but also the ground around the granary and underneath raised granaries.
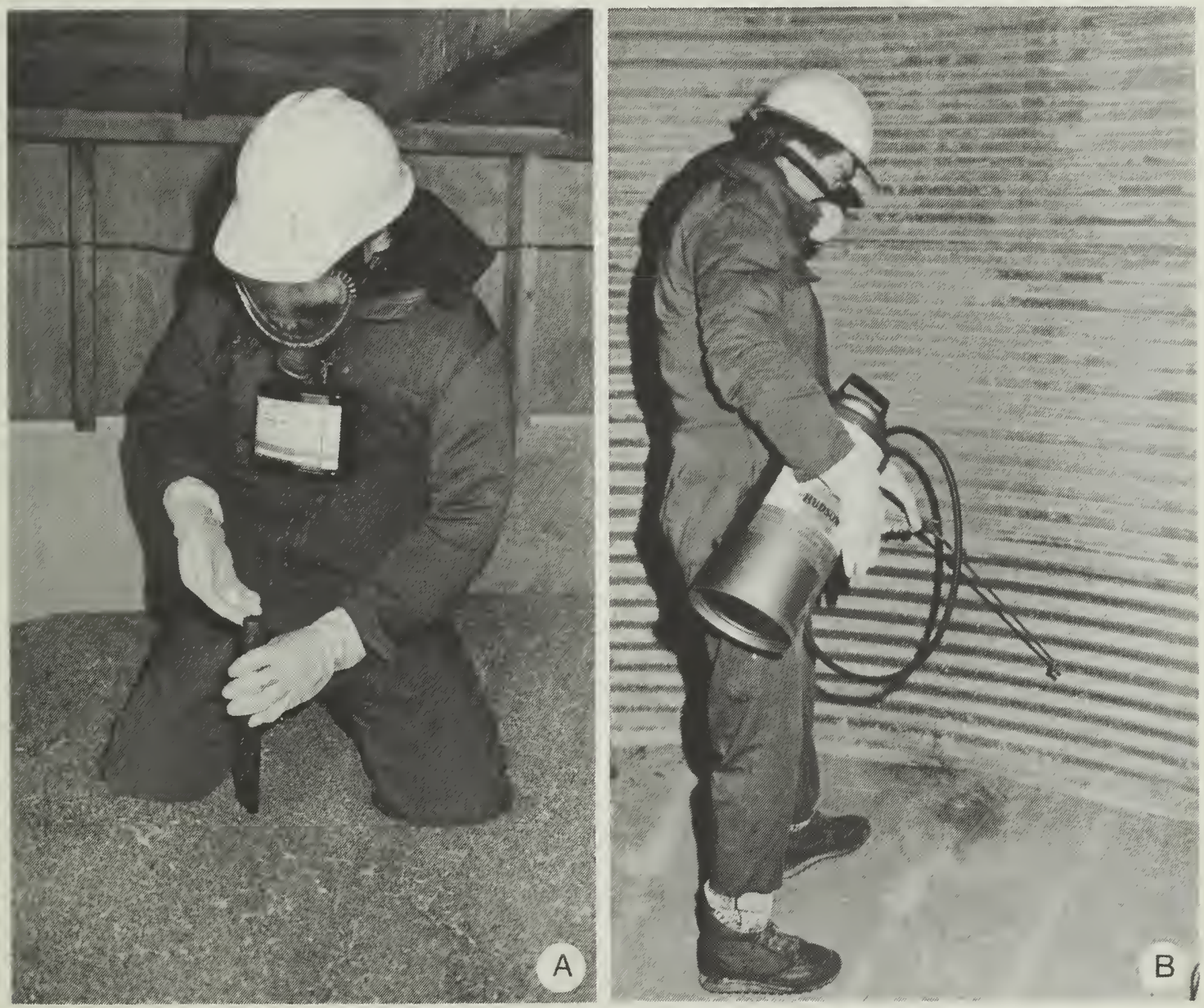

Fig. 12 Application of $A$, fumigant tablets to grain and $B$, contact insecticide to an empty granary. Note use of full-face gas mask, rubber gloves, coveralls, and hard hat. 


\section{Cautions for spray operators}

- Read insecticide labels and follow instructions on them.

- Examine the sprayer and hoses for leaks.

- Avoid spillage of insecticide.

- Use a protective mask with approved filters when applying insecticide in enclosed areas such as empty granaries.

- Wear protective clothing, hard hat, goggles, rubber work boots, and rubber gloves during preparation and spraying.

\section{Use of concentrates}

The amount of water needed to dilute emulsifiable concentrates or wettable powder formulations depends on the amount of insecticide in the concentrate and the dosage of insecticide recommended to control the pest. Use the following example to calculate how much water to add to a $50 \%$ emulsifiable concentrate to obtain a $1 \%$ spray solution of malathion:

$$
(50-1) / 1=49 / 1=49
$$

Therefore, add 1 part $(0.1 \mathrm{~L})$ of a $50 \%$ emulsion to 49 parts $(4.9 \mathrm{~L})$ of water to obtain a $1 \%$ spray.

Use a $1 \%$ spray of malathion to control rusty grain beetles in empty farm granaries. Apply the insecticide about 2-4 weeks before filling the granary although it can be applied as late as 1 day before storage. Apply the spray evenly with a portable compressed-air sprayer at $5 \mathrm{~L} / 100 \mathrm{~m}^{2}$ using a nozzle with a $0.4-\mathrm{mm}$ diameter orifice for emulsifiable concentrates or oil solutions and a $0.8-1.2-\mathrm{mm}$ diameter orifice for wettable powder solutions.

\section{Grain treatment}

Grain treatment is not a substitute for good housekeeping; however, special formulations of premium-grade malathion are available for treating cereals for long-term ( 8 months to 1 year) protection as it is being stored. Either liquid insecticide is sprayed on the grain, or dust composed of treated wheat flour is mixed with the grain at rates that are dependent on its flow through the auger.

Follow the instructions on the label Chemical odors may be produced that lower the selling price of grain if insecticides are applied at rates in excess of those recommended. Insecticide-treated grain should neither be sold for 7 days nor used for feed for 60 days after treatment. 
Table 2 Amount and rate of premium-grade malathion required for application

\begin{tabular}{cccc}
\hline \multicolumn{2}{c}{ Flow rate (wheat) } & & \multicolumn{2}{c}{ Application rate (1\% spray) } \\
$\mathrm{y}$ t/h & $\mathrm{t} / \mathrm{min}$ & $\mathrm{L} / \mathrm{h}$ & $\mathrm{L} / \mathrm{min}$ \\
\hline 3 & 0.05 & 2.4 & 0.04 \\
6 & 0.10 & 4.8 & 0.08 \\
9 & 0.15 & 7.2 & 0.12 \\
12 & 0.20 & 9.6 & 0.16 \\
15 & 0.25 & 12.0 & 0.20 \\
\hline
\end{tabular}

To treat the grain with a $1 \%$ spray of premium-grade malathion, apply it at $0.8 \mathrm{~L} / \mathrm{t}$ of wheat. Use Table 2 to determine the amount and rate of malathion for application. The treatment is effective as a protectant, 1 but the grain should be stored in good condition and contain less than $14 \%$ moisture, otherwise the insecticide will break down quickly, reducing its residual activity.

\section{FUMIGATING}

Fumigants generate toxic gases that are used to control insects in stored grain. They are available for farm use only as solid formulations. Fumigants are also toxic to humans and farm animals and, therefore, should be applied only by trained people. Avoid inhaling the vapors, and follow the directions on the container (see section on "Cautions for fumigators"). Although $\mathrm{CO}_{2}$ is registered for fumigation of grain, details related to cost, application, and exposure under Canadian conditions are still being studied.

The solid fumigant aluminum phosphide, which generates phosphine gas in the presence of air moisture, should be applied only when the following conditions are met:

- A person trained in fumigation is available to supervise. (In some provinces only licensed personnel may apply fumigants; in Alberta, a permit is required before the product can be purchased.)

- The grain temperature is at least $10^{\circ} \mathrm{C}$. Fumigants are most effective at temperatures higher than $20^{\circ} \mathrm{C}$. If the grain is below $5^{\circ} \mathrm{C}$, cool the grain to decrease the severity of the infestation by moving it to another bin or by aerating instead of fumigating.

1 The Canadian Grain Commission does not recommend the use of grain protectants for the following reasons:

- insect problems may not arise

- alternative control measures, such as aeration or grain movement, are available

- chemical residues remain in the grain. 
- The infested grain is stored in a granary that can be tightly sealed to retain the gas for at least 5 days by plugging cracks, crevices, and other openings.

- Rapid control of an infestation is needed before selling the grain.

- Full-face gas masks in good condition and with the appropriate canister for phosphine, rubber gloves, and protective clothing are available to wear during application.

- Gas-detector tubes or other detection equipment are available.

\section{Application}

In calculating fumigant dosage on the basis of bin volume, include the headspace above the grain. Use correct number of tablets or pellets as recommended by the manufacturer. Add tablets or pellets of solid fumigant (aluminum phosphide) either to the grain stream as it is discharged from an auger into a sealed bin or by probing them into the binned grain. Fumigate large bins by dropping the fumigant into the grain at regular intervals as the bin is being filled. Treat small bins of about 27 -t capacity by dropping the fumigant through metal pipes inserted into the grain (Fig. 12A). Select about 12 evenly spaced points on the surface of the grain and mark them with wooden stakes. Insert a pipe $3-\mathrm{cm}$ in diameter and $1.5 \mathrm{~m}$ long at each point and drop a tablet into the grain every $15 \mathrm{~cm}$ as the pipe is withdrawn. Start at the far end of the bin and work towards the door. Push some tablets into the auger hole before sealing.

In bins that cannot be tightly sealed at the top, cover the grain with polyethylene sheeting to reduce loss of fumigant and to improve effectiveness of treatment. 


\section{Cautions for fumigators}

When using fumigants, follow the directions on the label closely and especially take the following precautions:

- Always wear a full-face gas mask either when applying fumigant to binned grain or to grain during augering or when entering a fumigated bin. Respirators are ineffective on bearded men because a tight seal cannot be made around the face.

- Always fit a new canister in your gas mask before starting fumigation. Use the type of canister recommended for phosphine gas. A canister does not protect people exposed to heavy concentrations inside buildings (for gas levels above $2 \%$ in air) and does not supply oxygen.

- Always work with at least one other person.

- Wear rubber gloves, coveralls, and a hard hat.

- If an individual shows symptoms of overexposure to a fumigant, move that person to fresh air and call a doctor immediately. Symptoms of fumigant poisoning are dizziness, blurring of vision, vomiting, and abdominal pain.

- After applying the fumigant to a granary, nail or lock the doors, seal ventilators, and post warning signs on the door.

- After 1 week, open the ventilators, but do not enter until the granary has been checked for fumigant with a gas detector tube. Because fumigated grain can take several weeks to aerate during cold weather, check for residual gas with gas detector tubes from outside the bin before entry and inside during any prolonged period of work in the bin.

- Do not feed fumigated grain to livestock unless the grain has been shown to be gas free by detector tubes or other analyses.

- Always consider wind direction. If there is a dwelling or livestock close to and downwind from the structure to be fumigated, postpone fumigation until the wind subsides or changes direction.

- Do not fumigate when winds are strong.

- For your safety, position yourself upwind during application of fumigant to grain being augered into a bin. Avoid standing downwind from a bin under fumigation.

- Phosphine gas may react with certain metals, especially copper, brass, silver, and gold to cause corrosion at high temperatures and humidity. Take precautions to remove or protect equipment containing these metals, such as electric motors, wiring, and electronic systems. 


\section{FURTHER INFORMATION}

For more information on the control of infestations in farm-stored grain, write to the following:

- Research Station, Agriculture Canada, 195 Dafoe Road, Winnipeg, Man. R3T 2M9

- provincial entomologists at addresses listed in the Appendix

- provincial extension specialists or the entomologist, Canadian Grain Commission, 303 Main Street, Winnipeg, Man. R3C 3G8.

\section{ACKNOWLEDGMENTS}

The authors wish to thank R.W. Sims for photographs and illustrations, and also the many persons across Canada who reviewed and improved the text.

The contributions of the following organizations are gratefully acknowledged: United Grain Growers and the Saskatchewan Wheat Pool. 


\section{COMMON AND SCIENTIFIC NAMES OF MAJOR PESTS IN STORED GRAIN}

American black flour beetle

brown house moth

cadelle

cannibal mite

confused flour beetle

European black flour beetle

flat grain beetle

foreign grain beetle

glossy grain mite

grain mite

granary weevil

hairy spider beetle

Indianmeal moth

longhaired mite

meal moth

Mediterranean flour moth

mold mite

psocids

red flour beetle

rice weevil

rusty grain beetle

sawtoothed grain beetle sigmoid fungus beetle

squarenosed fungus beetle

warty grain mite

whiteshouldered house moth

yellow mealworm
Tribolium audax Halstead

Hofmannophila pseudospretella (Stainton)

Tenebroides mauritanicus (Linnaeus)

Cheyletus eruditus (Schrank)

Tribolium confusum Jacquelin du Val

Tribolium madens (Charpentier)

Cryptolestes pusillus (Schönherr)

Ahasverus advena (Waltl)

Tarsonemus granarius Lindquist

Acarus siro Linnaeus

Sitophilus granarius (Linnaeus)

Ptinus villiger (Reitter)

Plodia interpunctella (Hübner)

Lepidoglyphus destructor (Schrank)

Pyralis farinalis Linnaeus

Anagasta kuehniella (Zeller)

Tyrophagus putrescentiae (Schrank)

Lepinotus reticulatus Enderlein, Liposcelis bostrychophilus Badonnel, and other species

Tribolium castaneum (Herbst)

Sitophilus oryzae (Linnaeus)

Cryptolestes ferrugineus (Stephens)

Oryzaephilus surinamensis (Linnaeus)

Cryptophagus varus Woodroffe \& Coombs

Lathridius minutus (Linnaeus)

Aeroglyphus robustus (Banks)

Endrosis sarcitrella (Linnaeus)

Tenebrio molitor Linnaeus 


\section{REFERENCES}

Bousquet, Y. 1990. Beetles associated with stored products in Canada: An identification guide. Agric. Can. Publ. 1837. 224 pp.

Canadian Grain Commission. 1989. Official grain grading guide (1989 edition). Canadian Grain Commission, Winnipeg, Man. $253 \mathrm{pp}$.

Friesen, O.H.; Huminicki, D.N. 1987a. Grain aeration and unheated air drying. Man. Agric. Agdex 732.1. 30 pp.

Friesen, O.H.; Huminicki, D.N. 1987b. Fan test results. Man. Agric. Agdex 732.1. 30 pp.

McKenzie, B.A.; Van Fossen, L.; Stockdale, H.J. 1980. Managing dry grain in storage. Agric. Eng. Digest 20. 10 pp.

Mills, J.T. 1989. Spoilage and heating of stored agricultural products. Prevention, detection, and control. Agric. Can. Publ. 1823E. $101 \mathrm{pp}$.

Scotti, G. 1978. Les insectes et les acariens des céréales stockées. Institut Technique des Céréales et des Fourrages, Paris. 238 pp.

Sinha, R.N.; Watters, F.L. 1985. Insect pests of flour mills, grain elevators, and feed mills and their control. Agric. Can. Publ. 1776. $290 \mathrm{pp}$.

Trenholm, H.L.; Prelusky, D.B.; Young, J.C.; Miller, J.D. 1988. Reducing mycotoxins in animal feeds. Agric. Can. Publ. 1827/E. $22 \mathrm{pp}$.

Wilkins, D. 1983. Safe storage of wheat. Country Guide 102(9):30A, $30 D$.

\section{ADDITIONAL READING}

Anonymous. 1984. La conservation des grains secs. Gouvernement du Québec Ministère de l'Agriculture, des Pêcheries et de l'Alimentation. Publ. 84-0018. 48 pp.

Atlantic Agriculture. 1985. Field crop guide for the Atlantic Provinces 1985-1990. Ministries of Agriculture of New Brunswick, Prince Edward Island, Newfoundland, and Nova Scotia. Publ. 100. Agdex 100.32. $52 \mathrm{pp}$.

Bereza, K. 1986. Insects in farm-stored grain. Ontario Ministry of Agriculture and Food Publ. 229. Agdex 110.623. 12 pp.

Bond, E.J. 1984. Manual of fumigation for insect control. FAO Plant Prod. Prot. Paper 54. 432 pp. 
Friesen, O.H. 1981. Heated-air grain dryers. Agric. Can. Publ. 1700. $25 \mathrm{pp}$.

Gerber, H.S.; Buonassisi, A. 1988. Successful management of farmstored grain. Pest control notes. Ministry of Agriculture and Fisheries, British Columbia. 3 pp.

Morris, D.; Bereza, K. 1982. Harvesting and storing quality grain corn. Ontario Ministry of Agriculture and Food. Agdex 111.736. $5 \mathrm{pp}$.

Spieser, H. 1983. Digital thermometer for grain temperature sensing. Ontario Ministry of Agriculture and Food. Agdex 111.736. 4 pp. 



\section{APPENDIX}

The following addresses are listed as initial contacts for advice on grain-storage and handling problems:

Newfoundland \& Labrador

Extension Division

Provincial Agriculture Building Brookfield Road

P.O. Box 4750

ST. JOHN'S A1C 5T7

New Brunswick

Plant Health Section

Plant Industry Branch

New Brunswick Department of Agriculture

P.O. Box 6000

FREDERICTON E3B 5H1

\section{Nova Scotia}

Extension Services

Nova Scotia Agriculture

P.O. Box 550

TRURO B2N 5E3

\section{Prince Edward Island}

Extension Division

Agriculture Research and

Extension Building

University Avenue

CHARLOTTETOWN C1E 1E5

\section{Quebec}

Ministère de l'Agriculture

Pêcheries et Alimentation

C.P. 1693

QUEBEC G1K 7J8

\section{Ontario}

Advisory and Technical Services

Ontario Ministry of Agriculture and Food

Guelph Agriculture Centre

P.O. Box 1030

GUELPH N1H 6N1

\section{Manitoba}

Technical Services and Training

Branch

Marketing \& Production Division

Manitoba Agriculture

Norquay Building

401 York Avenue

WINNIPEG R3C 0P4

Saskatchewan

Extension Service

Saskatchewan Agriculture

Room 132 Walter Scott Building 3085 Albert Street

REGINA S4S 0B1

\section{Alberta}

Crop Protection Branch

Alberta Agriculture

The J.G. O'Donoghue Building

7000-113 Street

EDMONTON T6H 5T6

\section{British Columbia}

Plant Health Program

Crop Protection Branch

Ministry of Agriculture and

Fisheries

808 Douglas Street

VICTORIA V8W $2 Z 7$ 



\section{CONVERSION FACTORS FOR METRIC SYSTEM}

Imperial units

\section{Approximate}

Length

$\begin{array}{ll}\text { inch } & \times 25 \\ \text { foot } & \times 30 \\ \text { yard } & \times 0.9 \\ \text { mile } & \times 1.6\end{array}$

Results in

Area

square inch

square foot

square yard

square mile

acre

$\times 0.09$

$\times 0.836$

$\times 259$

$\times 0.40$

Volume

$\begin{array}{ll}\text { cubic inch } & \times 16 \\ \text { cubic foot } & \times 28 \\ \text { cubic yard } & \times 0.8 \\ \text { fluid ounce } & \times 28 \\ \text { pint } & \times 0.57 \\ \text { quart } & \times 1.1 \\ \text { gallon (Imp.) } & \times 4.5 \\ \text { gallon (U.S.) } & \times 3.8\end{array}$

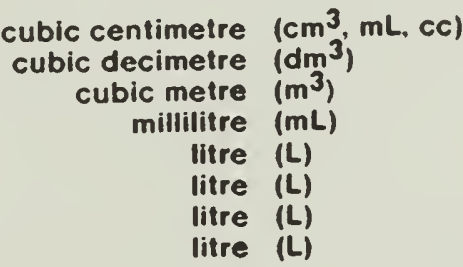

$\times 3.8$

Weight

$\begin{array}{ll}\text { ounce } & \times 28 \\ \text { pound } & \times 0.45 \\ \text { short ton (2000 lb) } & \times 0.9\end{array}$

$\begin{aligned} & \underset{\text { gram }}{(g)} \\ & \text { kilogram }(\mathbf{k g}) \\ & \text { tonne }(t)\end{aligned}$

\section{Temperature}

$\begin{array}{llr}\text { degrees Fahrenheit } & \left({ }^{\circ} \mathrm{F}-32\right) \times 0.56 \quad \text { degrees } \\ & \text { or }\left({ }^{\circ} \mathrm{F}-32\right) \times 5 / 9 \quad \text { Celsius }\left({ }^{\circ} \mathrm{C}\right)\end{array}$

\section{Pressure}

pounds per square inch $\times 6.9$

kilopascal (kPa)

Power
horsepower
$\times 746$
watt (W)
$\times 0.75$
kilowatt (kW)

\section{Speed}

$\begin{array}{llll}\begin{array}{l}\text { feet per second } \\ \text { miles per hour }\end{array} & \times 0.30 & \text { metres per second } & (\mathrm{m} / \mathrm{s}) \\ \text { kilometres per hour } & (\mathrm{km} / \mathrm{h})\end{array}$

\section{Agriculture}

gallons per acre $\quad \times 11.23$

quarts per acre $\times 2.8$

$\times$
$\times 1.4$

fluid ounces per acre $\times 70$

tons per acre

$\times$
$\times 2.24$

pounds per acre

$\times 1.12$

ounces per acre

$\times 70$

plants per acre

$$
\begin{array}{r}
2.47 \\
\hline
\end{array}
$$

litres per hectare (L/ha)
litres per hectare (L/ha)
litres per hectare (L/ha)
llilitres per hectare (mL/ha)
lonnes per hectare (t/ha)
grams per hectare (kg/ha)
grams per hectare (g/ha)
plants per hectare (plants/ha)




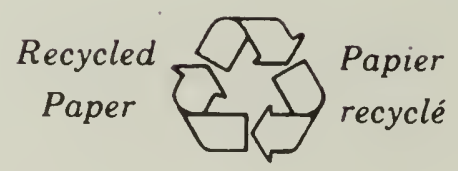

